\title{
Proliferative Defects and Formation of a Double Cortex in Mice Lacking Mltt4 and Cdh2 in the Dorsal Telencephalon
}

\author{
Cristina Gil-Sanz, ${ }^{1}$ Bruna Landeira, ${ }^{2}$ Cynthia Ramos, ${ }^{1}$ Marcos R. Costa, ${ }^{2}$ and Ulrich Müller ${ }^{1}$ \\ ${ }^{1}$ Department of Molecular and Cellular Neuroscience, Dorris Neuroscience Center, The Scripps Research Institute, La Jolla, California 92037, and ${ }^{2}$ Brain \\ Institute, Federal University of Rio Grande do Norte, Natal, Rio Grande do Norte 59056-450, Brazil
}

Radial glial cells (RGCs) in the ventricular neuroepithelium of the dorsal telencephalon are the progenitor cells for neocortical projection neurons and astrocytes. Here we show that the adherens junction proteins afadin and CDH2 are critical for the control of cell proliferation in the dorsal telencephalon and for the formation of its normal laminar structure. Inactivation of afadin or CDH2 in the dorsal telencephalon leads to a phenotype resembling subcortical band heterotopia, also known as "double cortex," a brain malformation in which heterotopic gray matter is interposed between zones of white matter. Adherens junctions between RGCs are disrupted in the mutants, progenitor cells are widely dispersed throughout the developing neocortex, and their proliferation is dramatically increased. Major subtypes of neocortical projection neurons are generated, but their integration into cell layers is disrupted. Our findings suggest that defects in adherens junctions components in mice massively affects progenitor cell proliferation and leads to a double cortex-like phenotype.

Key words: afadin; $\mathrm{CDH} 2$; double cortex; neocortex; progenitor; radial glia

\section{Introduction}

Radial glial cells (RGCs) of the dorsal telencephalon are the progenitor cells for neocortical projection neurons and astrocytes. Newly born neurons and astrocytes migrate from their place of birth near the ventricle toward the meninges to form the neocortical cell layers (Kriegstein and Noctor, 2004; Ayala et al., 2007; Franco and Müller, 2013; Greig et al., 2013). Defects in cell proliferation migration and differentiation lead to brain malformations, such as periventricular heterotopia, lissencephaly, and subcortical band heterotopia (SBH; des Portes et al., 1998; Sheen et al., 2004; Ferland et al., 2009). In SBH, also known as "double cortex," heterotopic gray matter is interposed between zones of white matter (Barkovich et al., 1994; Dobyns et al., 1999). The mechanisms that cause SBH have been proposed to involve defects in both the migration of neurons into the developing neocortical cell layers and the differentiation and proliferation of RGCs (Ross and Walsh, 2001; Bielas et al., 2004; Cappello et al., 2012).

RGCs project apical processes toward the ventricle and basal processes toward the meninges (Fishell and Kriegstein, 2003; Ra-

\footnotetext{
Received May 2, 2014; revised June 10, 2014; accepted June 13, 2014.

Author contributions: C.G.-S., B.L., M.R.C., and U.M. designed research;C.G.-S., B.L., and C.R. performed research; C.G.-S., B.L., and U.M. analyzed data; C.G.-S., B.L., M.R.C., and U.M. wrote the paper.

This work was supported by National Institutes of Health Grants NS046456 and HD070494 (U.M.), the Dorris Neuroscience Center (U.M.), the Skaggs Institute for Chemical Biology (U.M.), Ministry of Education Grant EX20090416 (C.G.-S.), Generalitat Valenciana Grant APOSTD/2010/064 (C.G.-S.), California Institute of Regenerative Medicine (C.G.-S.), and CAPES (Coordenação de Aperfeiçoamento de Pessoal de Nivel Superior) Foundation/Ministry of Education Grant PDSE 7640-13-7 (B.L.).

Correspondence should be addressed to Ulrich Müller, Dorris Neuroscience Center, The Scripps Research Institute, 10550 North Torrey Pines Road, La Jolla, CA 92037. E-mail: umueller@scripps.edu.

DOI:10.1523/JNEUROSCI.1793-14.2014

Copyright $\odot 2014$ the authors $\quad 0270-6474 / 14 / 3410475-13 \$ 15.00 / 0$
}

kic, 2003). The end feet of the apical processes are connected by adherens junctions that require for their formation $\mathrm{CDH} 2$, $\beta$-catenin, and $\alpha \mathrm{E}$-catenin (Brault et al., 2001; Machon et al., 2003; Junghans et al., 2005; Lien et al., 2006; Woodhead et al., 2006; Kadowaki et al., 2007; Tang et al., 2009). Inactivation of the small GTPase RhoA in the dorsal telencephalon of mice results in the disruption of adherens junctions and the formation of a double cortex (Cappello et al., 2012), suggesting a mechanistic link between perturbation in the adhesive interactions between RGCs and cortical lamination defects.

In epithelial cells, the localization and activity of cadherins is promoted by nectins, which are members of the Ig superfamily (Ikeda et al., 1999; Takahashi et al., 1999; Miyahara et al., 2000; Sato et al., 2006). The adaptor protein afadin links nectins and cadherins by binding to the cytoplasmic domains of nectins and associating with p120-catenin and $\alpha$-catenin (Takahashi et al., 1999; Tachibana et al., 2000; Pokutta et al., 2002; Hoshino et al., 2005), which in turn interact with the cytoplasmic domains of cadherins (Ozawa et al., 1989, 1990; Herrenknecht et al., 1991; Nagafuchi et al., 1991; Hirano et al., 1992; Knudsen and Wheelock, 1992; Reynolds et al., 1992). Without afadin, cadherin clustering is perturbed, leading to defects in the formation of adherens junctions (Ikeda et al., 1999; Sato et al., 2006). Although cadherins/catenins are required for adherens junction formation between RGCs, the role of afadin in this process is less clear. Afadin inactivation in RGCs at approximately E11.5 using nestin-Cre leads to progressive loss of adherens junctions (Yamamoto et al., 2013). The phenotype is restricted to some brain regions, and the severe hydrocephalus of the mutants has complicated mechanistic studies.

To further define the function of afadin in the neocortex, we generated a mouse line carrying a floxed allele of its gene (named 
Mtll4). We then inactivated Mtll4 expression using Emx1-Cre mice, which induces recombination in the dorsal telencephalon starting 1 day earlier than achieved with nestin-Cre (Gorski et al., 2002; Li et al., 2003; Dubois et al., 2006). The mutant offspring showed widespread disruption of adherens junctions between RGCs and a dramatic increase in progenitor proliferation, a phenotype that was even more pronounced in mice lacking $C d h 2$ in the dorsal telencephalon. Adult mice with a dorsal telencephalon-specific inactivation of either Mttl4 or Cdh2 exhibited a double cortex-like phenotype. These findings suggest that adherens junctions are critical for the control of progenitor cell proliferation during neocortical development and that mutations that affect adherens junction proteins can lead to a double cortex-like phenotype in mice.

\section{Materials and Methods}

Mice. Experiments using mice were performed under the oversight of an institutional review board. Mice carrying a floxed Mllt4 gene were generated using ES cell clones from European Conditional Mouse Mutagenesis Program (EUCOMM; HEPD0591_8_E01) with knockout first mutation (HEPD0591_8_E01; Ryder et al., 2013; http://www. mousephenotype.org/martsearch_ikmc_project/martsearch/ikmc_project/ 79371). ES clones were injected into C57BL/6J blastocysts, and the resulting chimeras were mated to $\mathrm{C} 57 \mathrm{BL} / 6 \mathrm{~J}$ females to obtain germ-line transmission. Offspring were genotyped by PCR using the following primers: G5arm, CATGTTTATT CTTGGTTTCAGCTGGG; G3arm, AACGACTTCACACCTTGACTAAGG; and LAR3, CAACGGGTTCTTCTG TTAGTCC. The sizes of the PCR products are $549 \mathrm{bp}$ (WT band) and $411 \mathrm{bp}$ (mutant band). Heterozygous F1 mice (Mllt $4^{\mathrm{KO}-f l o x /+}$ ) were mated with B6.Cg- $T g(A C T F L P e)$ mice (stock \#005703; The Jackson Laboratory) to remove the promoter-driven selection cassette of the knock-out first mutation, and the resulting offspring $\left(M l l t 4^{\text {flox-FLP/+ }}\right.$ ) were subsequently mated to $\mathrm{C} 57 \mathrm{BL} / 6 \mathrm{~J}$ mice to segregate the FLPe transgene. Heterozygous offspring $\left(\right.$ Mllt $\left.4^{f l o x /+}\right)$ were crossed to generate Mllt $4^{\text {flox/flox }}$ mice, and genotyping was performed by PCR (G5arm, CATGTTTATTCTTGGTTTCAGCTGGG; and G3arm, AACGACTTCACACCTTGACTAA GG). The sizes of the PCR products are $549 \mathrm{bp}$ (WT band) and $650 \mathrm{bp}$ (flox band). Mllt $4^{\text {flox/flox }}$ mice were mated to $E M X 1^{\text {Cre }}$ transgenic mice (Gorski et al., 2002) to generate Mllt4 $4^{f l o x /+} \mathrm{EMX}^{\mathrm{Cre} /+}$ mice, which were crossed with Mllt $4^{\text {flox/flox }}$ mice to obtain the animals used in the experiments. The presence of CRE was analyzed by PCR using previously published methods (Gorski et al., 2002). Cdh2 flox/flox mice (stock \#007611; The Jackson Laboratory) were crossed with $E m \times 1^{\text {Cre }}$ mice to generate $C d h 2^{\text {flox/+ }} \mathrm{Emxl}^{\mathrm{Cre} /+}$, which were crossed with $\mathrm{Cdh} 2^{\text {flox/flox }}$ to generate the animals used in the experiments.

Histology and immunostaining. Nissl staining and immunohistochemistry was performed as described previously (Franco et al., 2011, 2012; Gil-Sanz et al., 2013). Embryonic brains were dissected and fixed in $4 \%$ paraformaldehyde (PFA) overnight at $4^{\circ} \mathrm{C}$. Adult brains were transcardially perfused with $4 \%$ PFA, and brains were dissected and postfixed in $4 \%$ PFA overnight at $4^{\circ} \mathrm{C}$. Brains were sectioned coronally at 50 or 100 $\mu \mathrm{m}$ with a vibrating microtome (VT1200S; Leica) or at $12 \mu \mathrm{m}$ with a cryostat (CM 3050S; Leica). Sections used for 5-bromo-2'-deoxyuridine (BrdU) immunostaining were first treated with $2 \mathrm{~N} \mathrm{HCl}$ for $20 \mathrm{~min}$ and washed twice with borate buffer, $\mathrm{pH} 8.0$, to equilibrate. Antibodies used for immunostaining are as follows: anti- $\alpha$ E-catenin rabbit polyclonal (Cell Signaling Technology), anti-afadin rabbit polyclonal (Sigma), anti$\beta$-catenin mouse monoclonal (BD Biosciences), anti-BrdU mouse monoclonal (BD Biosciences), anti-BrdU rat monoclonal (AbD Serotec), anti-CDH2 mouse monoclonal (Sigma), anti-Ctip2 rat monoclonal (Abcam), anti-Cux1 rabbit polyclonal (Santa Cruz Biotechnology), antiGFAP rabbit polyclonal (Dako), anti-Ki67 rabbit polyclonal (Abcam), anti-Ki67 rat monoclonal (AbD Serotec), anti-L1 rat polyclonal (Millipore), anti-NeuN mouse monoclonal (Millipore), anti-Pax6 rabbit polyclonal (Covance), anti-phospho-Histone 3 (pH3) rabbit polyclonal (Cell Signaling Technology), anti-TAG1 mouse monoclonal (Developmental Studies Hybridoma Bank, National Institute of Child Health and Human
Development, and University of Iowa Department of Biology), anti-Tbr2 chicken (Millipore), anti-Tbr2 rabbit polyclonal (Abcam), and anti-Tuj1 mouse monoclonal (Covance). Nuclei were stained with DAPI (Thermo Fisher Scientific) and sections were mounted on slides with Prolong Gold mounting medium (Thermo Fisher Scientific). Images were captured using a Nikon-C2 or a Nikon-A1 laser-scanning confocal microscope and an Olympus AX70 microscope for bright-field images.

Quantifications and cell cycle analysis. At least three histological sections from three different animals at three distinct rostrocaudal levels for each genotype were analyzed for each immunostaining. Confocal optical sections were used for quantification. Cells were counted in columns from the ventricular zone (VZ) to the marginal zone (MZ). Values are mean \pm SEM. To measure the density of Pax6, Tbr2, or Ki67 cells, the number of positive cells was determined in an area including a column of the cortical primordium (from MZ to VZ) and normalized to $10^{4} \mu \mathrm{m}^{2}$. For quantifications in $C d h 2$ conditional knock-out (Cdh2-cKO) attributable to the severe hyperplasia that generates a dramatic increase of the thickness of the cortex, we evaluated the differences in the number of Pax6, Tbr2, or Ki67 cells in radial columns of the same thickness as in controls from the VZ to the MZ. To follow proliferating cells, we injected pregnant females intraperitoneally with BrdU (Sigma) at $150 \mu \mathrm{g} / \mathrm{g}$. Embryos were collected $30 \mathrm{~min}$ after the injection (to label cells during S-phase) and $24 \mathrm{~h}$ after the injection (to label cells in S-phase and some postmitotic neurons). $\mathrm{pH} 3$ labels cells in M-phase. Ki67 labels the cells in any phase of the cell cycle. For cell cycle quantifications, three parameters were analyzed: (1) quitting fraction, the proportion of BrdU-positive/ Ki67-negative $\left(\mathrm{BrdU}^{+} / \mathrm{Ki}^{-} 7^{-}\right)$cells among all BrdU ${ }^{+}$cells, $24 \mathrm{~h}$ after the injection; (2) BrdU labeling index, the proportion of $\mathrm{BrdU}^{+}$cells among all dividing $\mathrm{Ki} 7^{+}$cells, 30 min after the injection; and (3) mitotic index, proportion of the $\mathrm{pH} 3^{+}$cells among all dividing $\mathrm{Ki} 7^{+}$cells. Cells were counted using the count tool of Adobe Photoshop 6. Statistical analysis was performed using GraphPad Prism software 5.01.

\section{Results}

Double cortex-like phenotype in adult Afadin-cKO mice

Mice with a null mutation in the $M t t l 4$ gene die at approximately E10 (Ikeda et al., 1999), preventing an analysis of afadin function in neocortical development with a simple knock-out mouse line. To evaluate genetically the role of afadin during the development of the neocortex, we generated a mouse line carrying a floxed allele of the Mttl4 gene (Fig. 1A). To inactive Mttl4 expression, we crossed Mttl4-flox mice with Emx1-Cre mice that induced recombination as early as E10.5 in progenitor cells of the dorsal telencephalon (Gorski et al., 2002; Iwasato et al., 2004). For simplicity, we will refer to the mutant offspring $\left(M t t l 4^{f l o x / f o x} ; E m x^{C r e /+}\right)$ as Afadin-cKO mice. For all experiments, we compared the phenotype of Afadin-cKO mice with the phenotype of littermates that did not express Cre or contained only one floxed Mttl4 allele.

Afadin-cKO mice were born in the expected Mendelian frequency and survived into adulthood. In whole mounts, the dissected brain of the mutant mice at P25 appeared larger than in controls (data not shown). In Nissl stainings of cortical sections at several histological levels along the rostrocaudal axis of the brain, the most obvious difference was the increased size and severe disorganization of the neocortex in the Afadin-cKO mice (Fig. 1B). In control animals, cells in the neocortex were organized into cell layers above the cell-sparse white matter that contains axonal projections (Fig. $1 B$ ). In contrast, the cortex of Afadin-cKO mice contained a thin layer of cells near the meninges and a disorganized mass of cells heterotopically localized deeper within the cortex (Fig. 1B). This mass of heterotopic cells was flanked above and below by relatively cell sparse regions (Fig. $1 B$ ). Hippocampal structure was overall preserved but less well organized.

Staining with NeuN confirmed that the thin band of cells near the meninges and the heterotopia contained differentiated neu- 


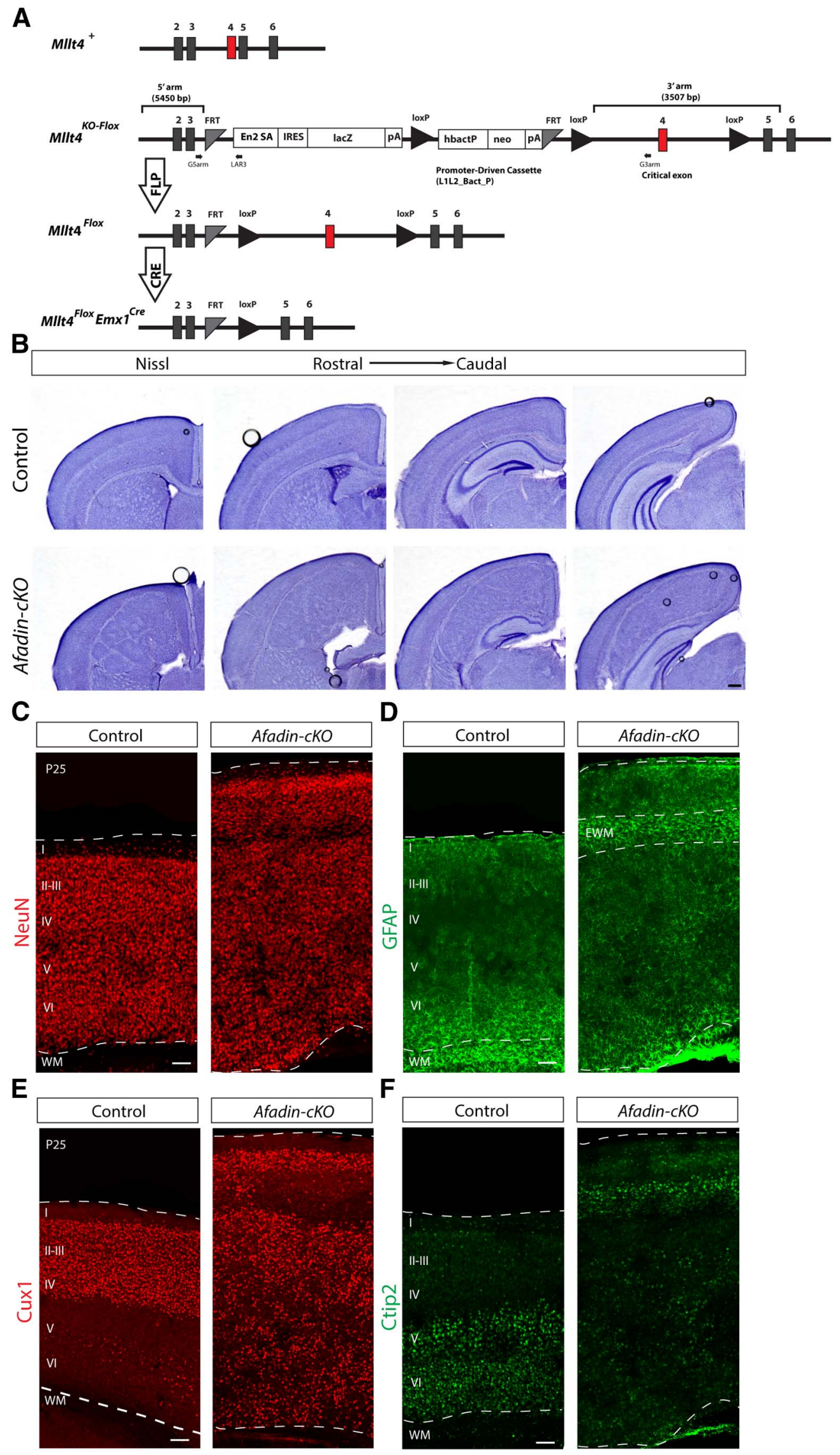

Figure 1. Afadin deletion from cortical progenitors causes SBH or double cortex. A, Afadin-cKO generation. Schematic diagram of wild-type $(+)$, knock-out first mutation with conditional potential (KO-flox), floxed ( flox), and Cre-recombined alleles of the Mllt4 gene. The EUCOMM "knock-out first" allele (KO-flox) contains an IRES: lacZ trapping cassette and a (Figure legend continues.) 
rons (Fig. 1C). Immunostaining with the astrocyte marker GFAP that labels fibrous astrocytes within the white matter revealed the accumulation of $\mathrm{GFAP}^{+}$cells in the relatively cell-sparse regions flanking the heterotopia (Fig. 1D). The histological features in Afadin-cKO mice resemble the phenotype described for SBH/ double cortex, a defect originally associated with defects in neuronal migration (Ross and Walsh, 2001; Bielas et al., 2004) but more recently also linked to alterations in the function of RGCs (Cappello et al., 2012).

Next we used immunohistochemistry to analyze the distribution of $\mathrm{Cux}^{+}{ }^{+}$upper layer neurons and Ctip2 ${ }^{+}$lower layer neurons in Afadin-cKO mice. $\mathrm{Cux}^{+}$cells were abundant in both the thin layer of cells close to the meninges and the heterotopia that were situated deeper in the neocortex (Fig. 1E). Ctip2 ${ }^{+}$cells were prominently present in the thin band of cells close to the meninges and scattered throughout the ectopia (Fig. $1 F$ ). These findings suggest that at least some subtypes of cortical projection neurons are generated in Afadin-cKO mice but that their assembly into neocortical cell layers is perturbed. The histological features of the neocortex in Afadin-cKO mice are similar to those observed in SBH/double cortex caused by mutations in other genes, such as DCX in humans (des Portes et al., 1998; Gleeson et al., 1998) and RhoA in mice (Cappello et al., 2012).

\section{Disruption of adherens junctions in Afadin-cKO mice}

To define the mechanism by which afadin affects neocortical development, we analyzed its expression pattern in the developing dorsal telencephalon. Using immunohistochemistry on sections of E13.5 mice, we confirmed that afadin is expressed throughout the developing dorsal telencephalon, with highest expression levels near the ventricle in which the end feet of RGCs are connected by adherens junctions (Fig. $2 A, B$ ). At the ventricle, afadin was colocalized with $\mathrm{CDH} 2, \beta$-catenin, and $\alpha \mathrm{E}$-catenin (Fig. $2 B, C$ ), suggesting that it cooperates with these proteins in the formation of adherens junctions. In Afadin-cKO mice, expression of afadin was maintained in the $\mathrm{VZ}$ of the ganglionic eminence but not in the $\mathrm{VZ}$ of the dorsal telencephalon in which Emx1-Cre is expressed (Fig. 2D,E). However, afadin expression was maintained in blood vessels within the neocortex of the mutant mice (Fig. 2D, arrows).

To determine the extent to which lack of afadin in the neuroepitelial cells disrupted adherens junctions between RGCs, we analyzed the distribution of three additional junctional proteins (CDH2, $\beta$-catenin, and $\alpha$ E-catenin) at E13.5. Unlike in control mice, the distribution of the three proteins was severely per-

$\leftarrow$

(Figure legend continued.) floxed promoter-driven neo cassette inserted into an intron of the targeted gene. Engrailed (En2) splice acceptor disrupts gene function, resulting in a lacZ fusion for studying gene expression. Flp recombinase removes the gene trap cassette, converts the "knock-out first" allele to a conditional allele ( flox). Cre recombinase deletes the floxed exon of the conditional allele resulting in a frame shift and null mutation (modified from Ryder et al., 2013). Numbered boxes represent exons. Red box represents the critical exon. PCR primers for genotyping (G5arm, G3arm, and LAR3) are indicated. B, Niss I staining showing coronal sections of adult brains from control and Afadin-CKO mice at several histological levels along the rostrocaudal axis of the neocortex. Note the enlarged neocortex and the ectopic mass of cells surrounded by cell-sparse regions in the mutant mice. Scale bar, $500 \mu \mathrm{m}$. C, D, Coronal sections of adult brains from control and Afadin-CKO mice immunostained with the neuronal marker NeuN (red; $\boldsymbol{C}$ ) and with the astrocyte marker GFAP (green; $\boldsymbol{D}$ ). Note the ectopic accumulation of $\mathrm{GFAP}^{+}$astrocytes, presumably ectopic white matter, in the upper part of the cortex of the mutant mice. Scale bar, $100 \mu \mathrm{m} . \boldsymbol{E}, \boldsymbol{F}$, Coronal sections of adult brains from control and AfadinCKO mice immunostained with the upper layer marker $C u x 1(\operatorname{red} ; \boldsymbol{E})$ and the lower layer marker Ctip2 (green; $\boldsymbol{F}$ ). Note the abnormal distribution of the cells in the Afadin-cKO mice. Scale bar, $100 \mu \mathrm{m}$. I-VI, layers I-VI; WM, white matter; EWM, ectopic white matter. turbed (Fig. 2E,F). Afadin expression was no longer detectable (Fig. $2 E$ ), $\mathrm{CDH} 2$ and $\beta$-catenin were distributed more evenly around the cell surface (Fig. $2 E, F$ ), and $\alpha$ E-catenin was distributed diffusely throughout the cell (Fig. $2 F$ ). This redistribution of proteins is consistently observed when adherens junctions are disrupted (Junghans et al., 2005; Lien et al., 2006; Sato et al., 2006; Rasin et al., 2007; Yamamoto et al., 2013), suggesting that, in Afadin-cKO mice, adherens junctions were not properly formed or maintained.

\section{Dispersion of proliferating progenitor cells in Afadin-cKO mice}

To determine the temporal progression of the neocortical phenotype in Afadin-cKO mice, we analyzed histological sections of control and mutant mice at E13.5 and E16.5. At E13.5, the thickness of the developing neocortex was substantially increased in Afadin-cKO mice compared with controls as revealed by staining of nuclei with DAPI (Fig. 3A). Consistent with defects in the integrity of adherens junctions, the ventricular surface was disrupted and irregular in the mutants (Fig. 3A). At E16.5, the neocortex of the Afadin-cKO mice was severely disorganized and appeared hyperplastic (Fig. $3 F$ ).

We next used molecular markers to determine the distribution of progenitor cells and neurons within the developing neocortex of Afadin-cKO mice. We used Pax6 as a marker for RGCs, Tbr2 as a marker for intermediate progenitors, and TuJ1 as a marker for differentiated neurons (Caccamo et al., 1989; Lee et al., 1990a,,b; Götz et al., 1998; Englund et al., 2005). Staining with Ki67 at E13.5 and E16.5 revealed that proliferating cells were primarily confined to the VZ and subventricular zone (SVZ) of control mice but broadly distributed throughout the entire thickness of the nascent neocortex in Afadin-cKO mice (Fig. $3 B, G$ ). Consistent with this finding, in controls at E13.5, Pax6 ${ }^{+}$RGCs were primarily concentrated in the VZ (Fig. $3 C$ ), Tbr2 ${ }^{+}$intermediate progenitors in the SVZ (Fig. $3 D$ ), and Tuj $1^{+}$neurons in the nascent cortical plate (Fig. $3 E$ ). In contrast, Pax $6^{+}$RGCs and $\mathrm{Tbr} 2^{+}$intermediate progenitors in the mutants were dispersed throughout the entire developing neocortex (Fig. 3C,D); Tuj1 ${ }^{+}$ neurons were distributed irregularly with some of them occupying positions within the VZ and SVZ (Fig. 3E). At E16.5, a similarly abnormal distribution of $\mathrm{Pax}^{+}$and $\mathrm{Tbr} 2^{+}$progenitors throughout the entire thickness of the developing neocortex was observed in Afadin-cKO mice (Fig. $3 \mathrm{H}, \mathrm{I}$ ). In addition, staining with Tuj1 revealed an abnormally thin cortical plate and accumulations of neurons at the surface of the ventricle and below the intermediate zone in which they formed rosette-like structures (Fig. 3J).

To further ascertain the distribution of $\mathrm{Pax}^{+}{ }^{+}$RGCs and $\mathrm{Tbr}^{+}{ }^{+}$intermediate progenitors, we also performed doubleimmunofluorescence microscopy (Fig. $4 A$ ). The two markers were still primarily expressed in distinct cell populations, indicating that deletion of afadin did not lead to the generation of a progenitor with a mixed RGC/intermediate progenitor identity.

Finally, we anticipated that the gross disruption of the laminar structure of the neocortex would affect the organization of axonal tracts in the mutant mice. Staining with antibodies to TAG1 and L1 revealed massive perturbations in axonal tracts (Fig. 4B). Although these perturbations are likely at least in part a secondary consequence of defects in cell numbers and cell position, we cannot exclude that afadin also plays a more direct role in axonal outgrowth or pathfinding. 
A
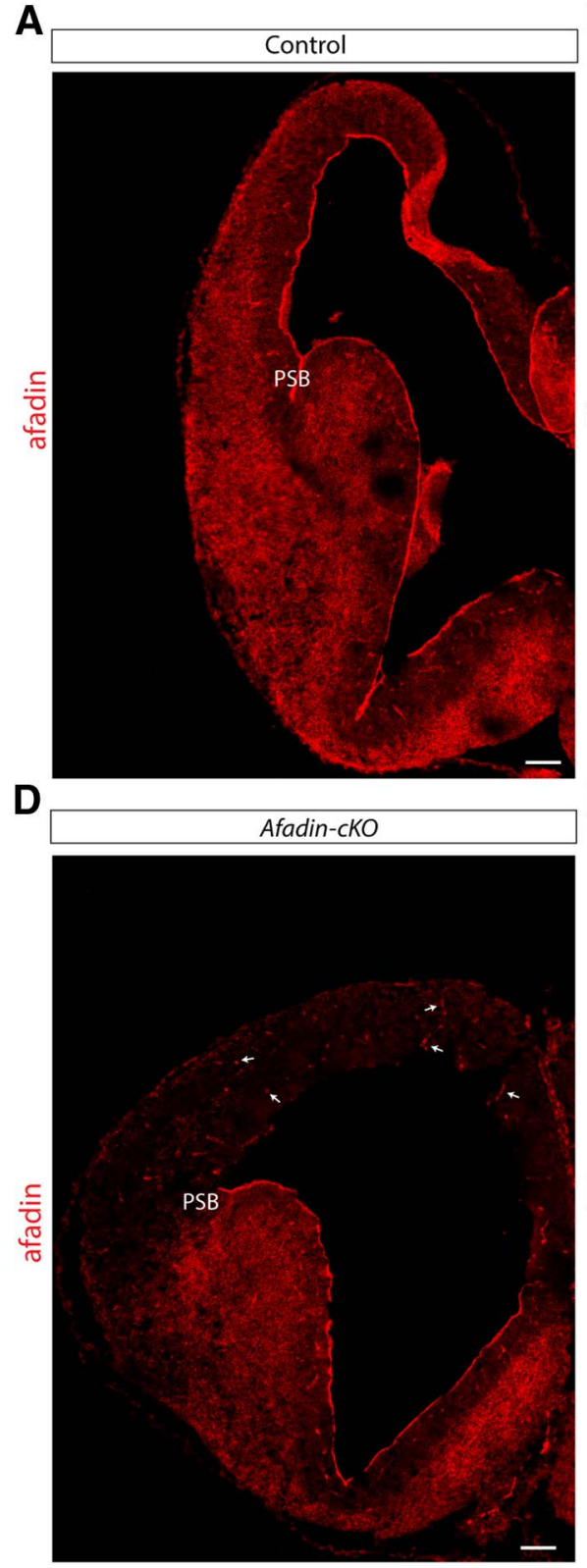

B

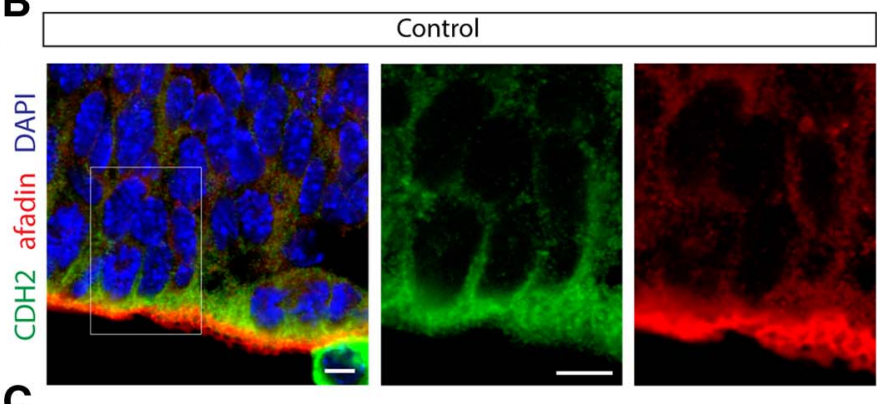

C
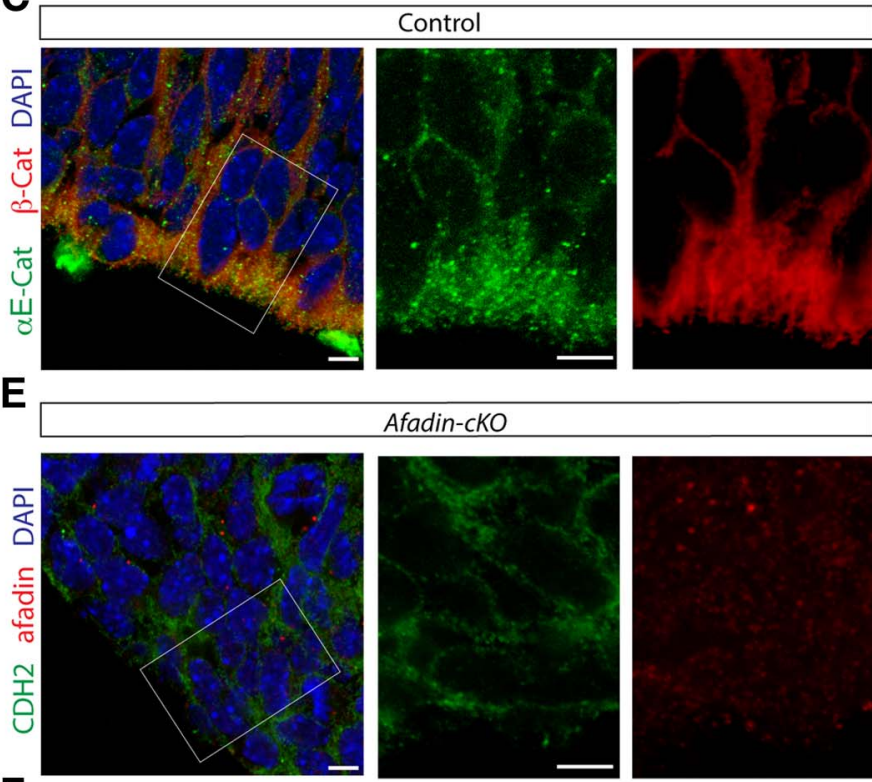

$\mathbf{F}$

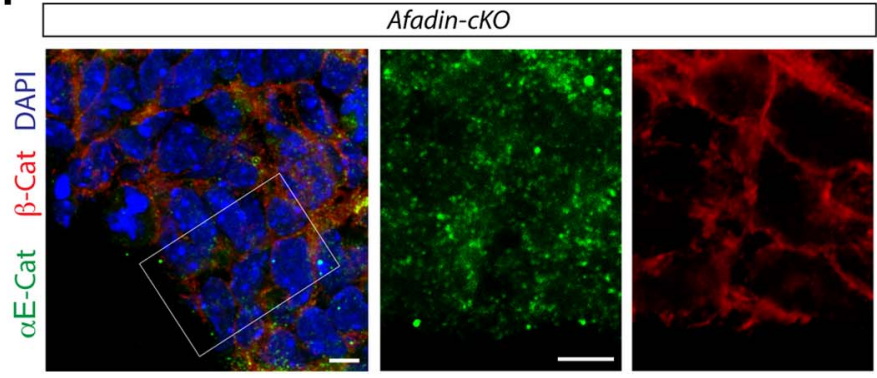

Figure 2. Afadin-CKO mice present disruption of the cortical adherens junctions. $\boldsymbol{A}$, Coronal section of the brain of control mice at E13.5 immunostained for afadin protein. Note the accumulation of afadin at the ventricular surface of the pallium and subpallium. Scale bar, $100 \mu \mathrm{m}$. B. Coronal section of the E13.5 developing cortex of control mice showing the VZ immunostained for the junctional proteins CDH2 (green) and afadin (red). Nuclei stained with DAPl are shown in blue. Scale bars, $5 \mu \mathrm{m}$. C, Coronal section of the E13.5 developing cortex of control mice showing the VZ immunostained for the junctional proteins $\alpha \mathrm{E}$-catenin (green) and $\beta$-catenin (red). Nuclei stained with DAPI are shown in blue. Scale bars, $5 \mu \mathrm{m}$. $\boldsymbol{D}$, Coronal section of the brain of Afadin-CKO mice at E13.5 immunostained for afadin protein. Note the disappearance of afadin immunostaining in the dorsal telencephalon, whereas afadin expression is maintained in the subpallium. Arrows point toward blood vessels in the dorsal pallium, which also continue to express afadin. Scale bar, $100 \mu \mathrm{m}$. $\boldsymbol{E}$, Coronal section of the E13.5 developing cortex of Afadin-CKO mice showing the VZ immunostained with the junctional proteins (DH2 (green) and afadin (red). Note the absence of afadin expression and the altered localization of CDH2 at the apical-junctional complex. Nuclei stained with DAPI are shown in blue. Scale bars, $5 \mu \mathrm{m}$. $\boldsymbol{F}$, Coronal section of the E13.5 developing cortex of Afadin-cKO mice showing the VZ immunostained with the junctional proteins $\alpha \mathrm{E}$-catenin (green) and $\beta$-catenin (red). Note the altered localization of both proteins at the apicaljunctional complex. Nuclei stained with DAPI are shown in blue. Scale bars, $5 \mu \mathrm{m}$. PSB, Pallial-subpallial boundary.

\section{Defects in cell proliferation in Afadin-cKO mice}

The thickness of the neocortex appeared to be increased in Afadin-cKO mice already at embryonic ages. This could be a consequence of the generation of abnormal numbers of cells. Consistent with this hypothesis, the numbers of Ki67 ${ }^{+}$cells was increased at $\mathrm{E} 13.5$ by $\sim 50 \%$ in the mutant mice, with an approximately equal increase in the number of $\mathrm{Pax}^{+}{ }^{+} \mathrm{RGC}$ and $\mathrm{Tbr} 2{ }^{+}$intermediate progenitors (Fig. $5 A-C$ ). Increases in the number of proliferative cells could be caused by a reduc- tion in the number of progenitor cells that exited the cell cycle. To test this hypothesis, we injected pregnant females at E12.5 with BrdU to label cells in S-phase and prepared histological sections of the embryos $24 \mathrm{~h}$ later. We stained the sections for BrdU and Ki67, the latter labeling proliferating cells throughout different stages of the cell cycle. Cells that do not leave the cell cycle within the $24 \mathrm{~h}$ period are therefore double positive for BrdU and Ki67, whereas cells that exited the cell cycle are positive for BrdU only. The number of 

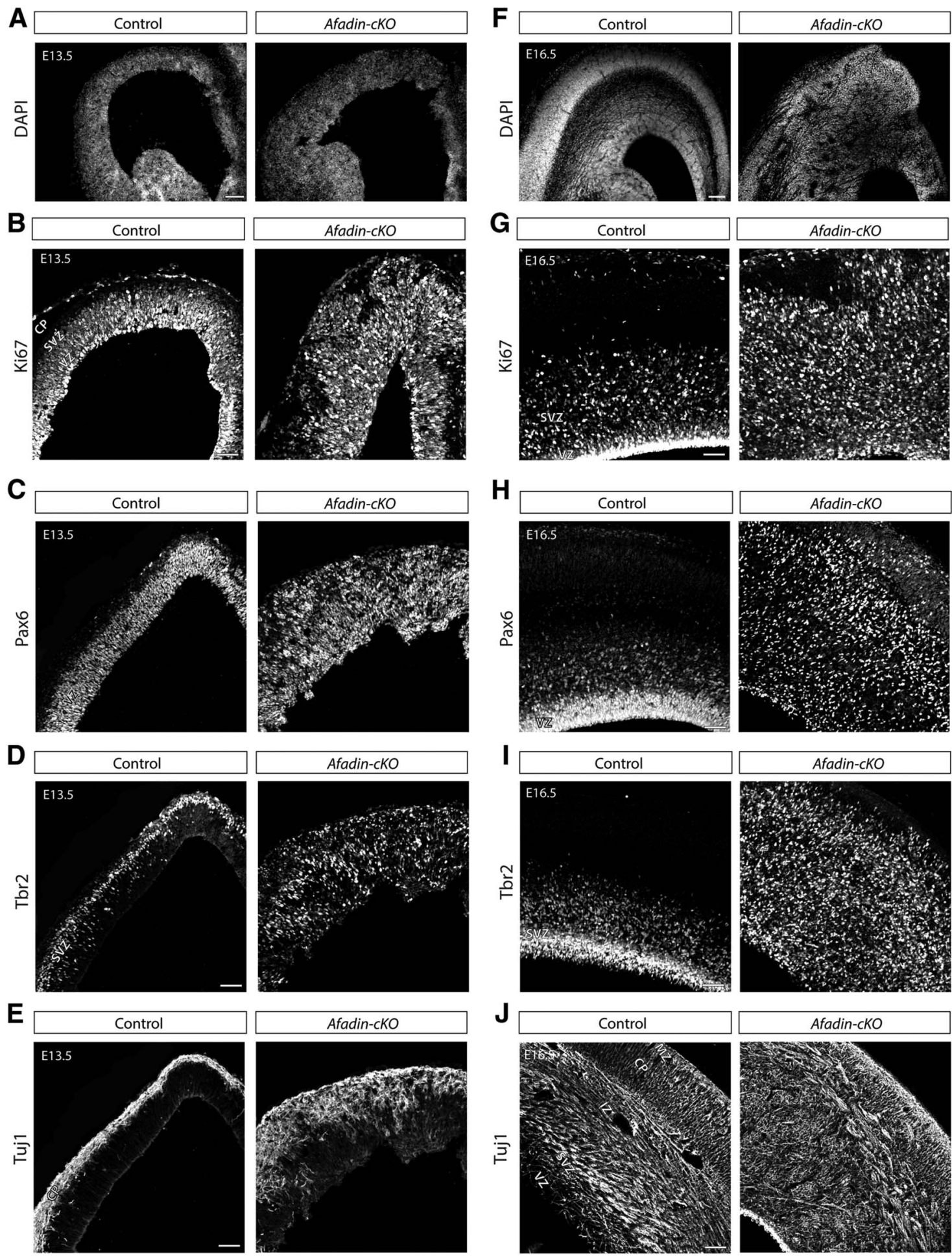

Figure 3. Hyperplasia in the developing neocortex of Afadin-CKO mice. Overview of the developing neocortex from control and Afadin-CKO at E13.5 and E16.5 stained with the nuclear marker DAP $(\boldsymbol{A}-\boldsymbol{F})$, the proliferation marker Ki67 $(\boldsymbol{B}-\boldsymbol{G})$, the radial glia cell marker Pax6 $(\boldsymbol{C}-\boldsymbol{H})$, the intermediate progenitor marker Tbr2 $(\boldsymbol{D}-\boldsymbol{I})$, and the neuronal marker Tuj-1 $(\boldsymbol{E}-\boldsymbol{J})$. Note the general disorganization of the cortical cells and axon bundles in the mutant mice. The increased size of the cortex in the Afadin-cKO mice is visible at E13.5 and E16.5. Scale bars, $100 \mu \mathrm{m}$. CP, Cortical plate; IZ, intermediate zone.

$\mathrm{BrdU}^{+} / \mathrm{Ki}^{-} 7^{-}$cells was strongly reduced $(\sim 43 \%$ decrease $)$ in Afadin-cKO mice (Fig. $5 D, E$ ), suggesting an alteration of cell cycle withdrawal in the mutant mice. To measure cell cycle length, we calculated the BrdU labeling index by labeling progenitors for 30 min with BrdU, followed by immunostaining for BrdU and Ki67 (Fig. $5 F, G$ ). The percentage of $\mathrm{BrdU}^{+} /$
$\mathrm{Ki} 67^{+}$cells was increased by $\sim 25 \%$, indicative of a shortened cell cycle in the progenitors in Afadin-cKO mice. Finally, we calculated the mitotic index, the proportion of dividing cells in M-phase. Immunostaining for Ki67 and the M-phase marker $\mathrm{pH} 3$ demonstrated an $\sim 50 \%$ increase in the number of $\mathrm{Ki} 7^{+/} \mathrm{pH}^{+}$cells (Fig. $5 \mathrm{H}, I$ ). Together, these data dem- 
A

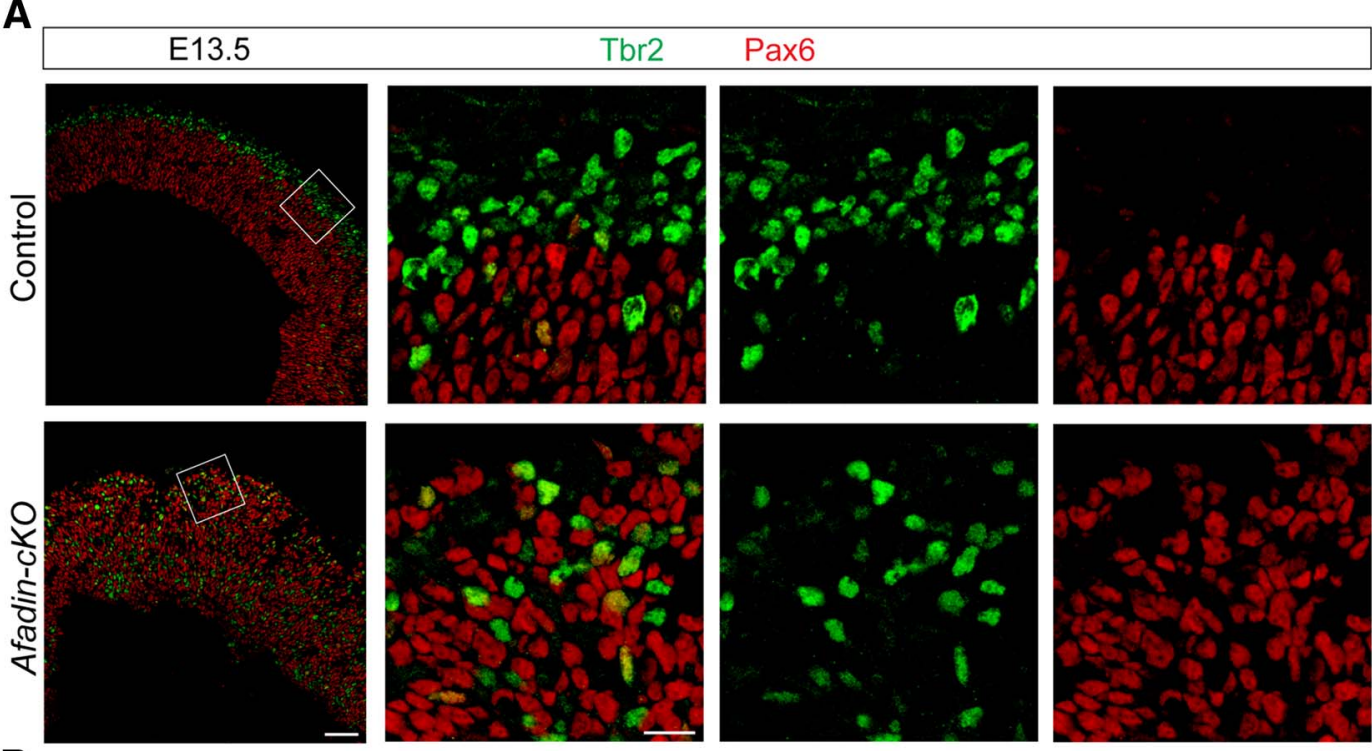

B
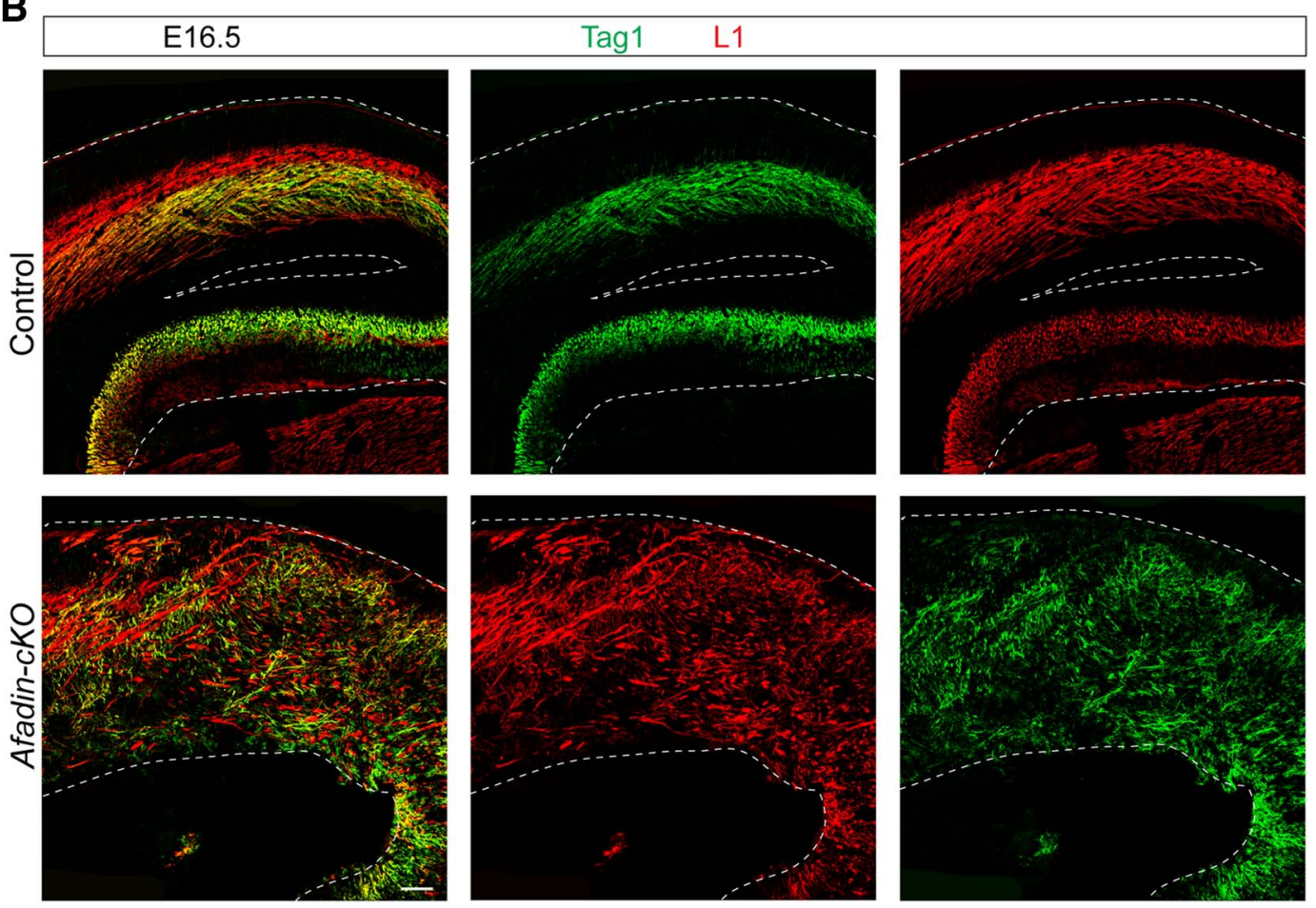

Figure 4. Progenitor distribution and axonal projections in Afadin-cKO mice. A, Coronal brain sections from control and Afadin-cKO mice at E13.5 were stained with antibodies to Pax6 (red) and Tbr2 (green). Note that the two markers are primarily expressed in non-overlapping cell populations, even in mutant animals. Scale bars: overviews, $100 \mu \mathrm{m} ;$ insets, $25 \mu \mathrm{m} . \boldsymbol{B}$, Coronal brain sections from control and Afadin-CKO mice at E16.5 were stained with antibodies to TAG1 (green) and L1 (red) to reveal axonal projections. Note the gross disorganization of axonal tracts in the mutants. Scale bar, $100 \mu \mathrm{m}$.

onstrate that cell cycle regulation and proliferation are significantly altered in Afadin-cKO mice.

Defects in adherens junctions, cell proliferation, and axonal pathfinding in $\mathrm{CDH} 2$ mutant mice

In epithelial cells, nectins cooperate with cadherins in the assembly of adherens junctions (Ikeda et al., 1999; Takahashi et al., 1999; Miyahara et al., 2000; Sato et al., 2006). The adaptor protein afadin links nectins and cadherins by binding to the cytoplasmic domains of nectins and associating with p120-catenin and $\alpha$-catenin (Takahashi et al., 1999; Tachibana et al., 2000; Pokutta et al., 2002; Hoshino et al., 2005), which in turn interact with the cytoplasmic domains of cadherins (Fig. 6A; Ozawa et al., 1989, 1990; Herrenknecht et al., 1991; Nagafuchi et al., 1991; Hirano et al., 1992; Knudsen and Wheelock, 1992; Reynolds et al., 1992). Without afadin, cadherin clustering is perturbed, leading to defects in the formation of adherens junctions (Ikeda et al., 1999; Sato et al., 2006). Therefore, we wondered whether there is a mechanistic link between afadin and cadherins in RGCs.

Adherens junctions are disrupted in mice lacking either $\mathrm{CDH} 2$ or $\alpha \mathrm{E}$-catenin, but proliferative defects similar to those reported here were only reported for $\alpha \mathrm{E}$-catenin-deficient mice (Lien et al., 2006; Kadowaki et al., 2007). This suggests that afadin and $\alpha \mathrm{E}$-catenin might have specific functions in controlling pro- 
A

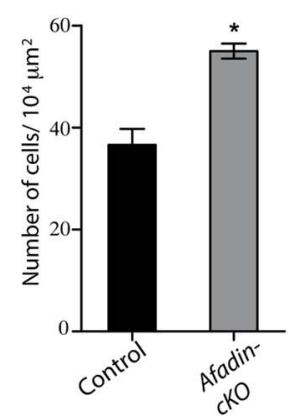

D
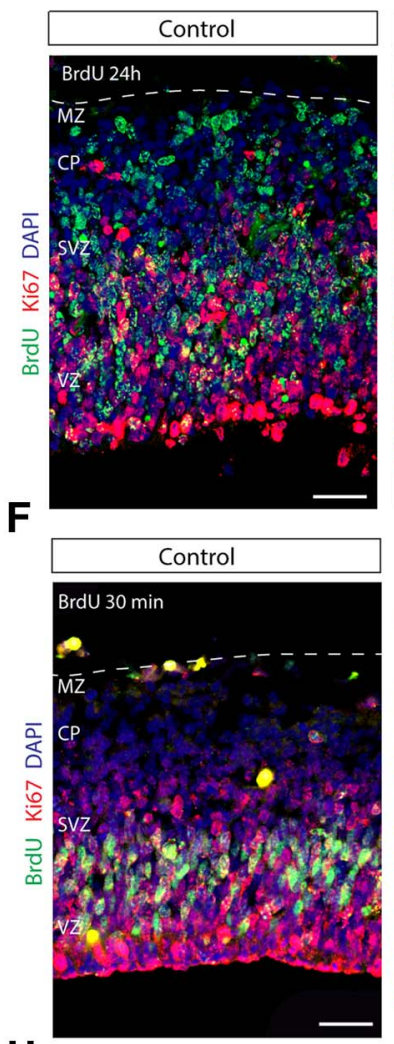

H

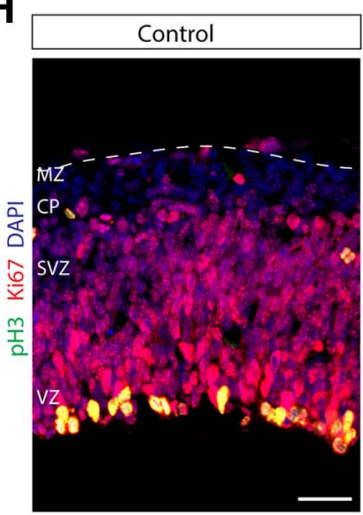

B
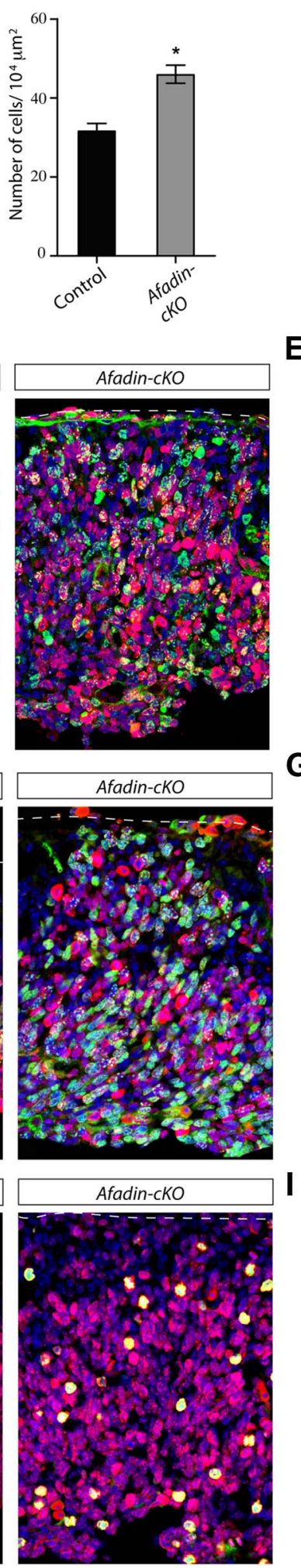

C

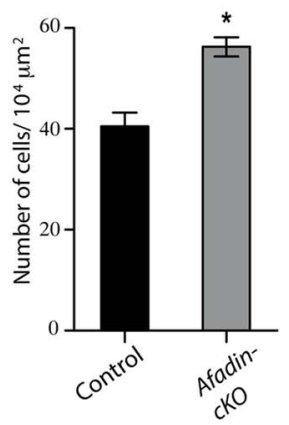

$\mathbf{E}$

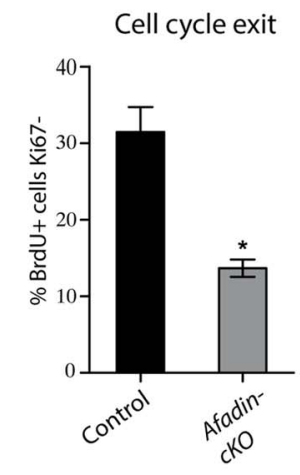

G
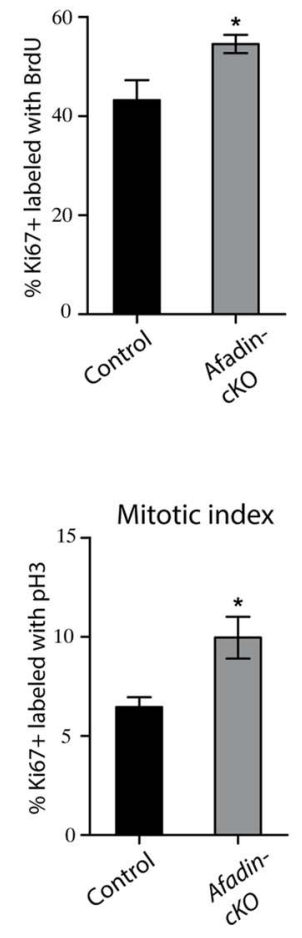

Figure 5. Increased proliferation of cortical progenitor cells in Afadin-CKO mice. $A$, Quantification (mean \pm SEM) of the number of RGCs (Pax6 ${ }^{+}$cells) in control and Afadin-CKO mice at E13.5. ${ }^{*} p<0.0001$ by Student's $t$ test. $\boldsymbol{B}$, Quantification (mean \pm SEM) of the number of intermediate progenitor cells ( $\mathrm{Tbr2}{ }^{+}$cells) in control and Afadin-cKO mice at E13.5. ${ }^{*} p<0.0005$ by Student's test. C, Quantification (mean \pm SEM) of the number of proliferating cells (Ki67 ${ }^{+}$cells) in control and Afadin-CKO mice at E13.5. ${ }^{*} p<0.0005$ by Student's $t$ test. $\boldsymbol{D}, \boldsymbol{E}$, The deletion of afadin causes a decrease in cell cycle exit. $\boldsymbol{D}$, Coronal sections of control and Afadin-CKO brains at E13.5 showing the neocortex immunostained with BrdU (green) and Ki67 (red). Nuclei stained with DAPI are shown in blue. Pregnant females were injected with BrdU $24 \mathrm{~h}$ before the animals were euthanized. Cells reentering the cell cycle are BrdU ${ }^{+} \mathrm{Ki}_{67}{ }^{+}$, whereas cells withdrawn from the cell cycle are BrdU ${ }^{+} \mathrm{Ki} 67^{-}$. Scale bar, $50 \mu \mathrm{m}$. E, Quantification (mean \pm SEM)

liferation. Alternatively, disruption of adherens junctions more generally might affect proliferation. Defects after disruption of the $C d h 2$ gene might have escaped detection in previous studies (Kadowaki et al., 2007), possibly because of incomplete gene inactivation with the Cre mice used in previous studies. To distinguish between these possibilities, we crossed $C d h 2^{f l o x}$ flox mice with Emx1-Cre mice to generate Cdh2-cKO mice. By P13, the cortex of $C d h 2-c K O$ mice was even more hyperplastic than in Afadin-cKO mice and vastly increased in size (Fig. 6B). The laminar structure was disrupted, and a massive heterotopia formed below a thin band of cells near the meninges (Fig. $6 B)$.

Neurons expressing NeuN, Cux1, and CTIP2 were observed in the thin band of cells near the meninges and in the heterotopia (Fig. $6 C, D$ ). $\mathrm{GFAP}^{+}$cells accumulated in the relatively cell-sparse cell regions flanking the heterotopia (Fig. $6 C$ ). Therefore, the histological features of Cdh2-cKO mice closely resemble the phenotype of Afadin-cKO mice.

Immunohistochemical analysis at E13.5 confirmed that the localization of adherens junction proteins was perturbed in the $\mathrm{VZ}$ of the developing dorsal telencephalon of Cdh2-cKO mice (Fig. 7A,B). Afadin expression levels seemed reduced (Fig. 7B), although this could be a consequence of broader distribution of afadin protein throughout the cytoplasm. In addition, $\mathrm{Pax} 6^{+}$and $\mathrm{Tbr} 2^{+}$progenitor cells and $\mathrm{Tuj}^{+}$neurons were distributed through the entire thickness of the abnormal neocortex (Fig. $7 C, D$ ). The distribution of the cells was not homogenous, and numerous rosette-like structures were detected, which was especially obvious when sections were stained for Tuj1 (Fig. 7D).

\footnotetext{
$\leftarrow$

of the data in $\boldsymbol{D}$. ${ }^{*} p<0.0001$ by Student's test. $\boldsymbol{F}, \boldsymbol{G}$, Cell cycle length is decreased in progenitors from Afadin-cKO mice at E13.5. $\boldsymbol{F}$, Coronal sections of control and Afadin-CKO brains at E13.5 showing the neocortex immunostained with BrdU (green) and Ki67 (red). Nuclei stained with DAPI are shown in blue. The percentage of $\mathrm{Ki} 7^{+}$progenitors labeled with BrdU after a 30 min pulse was calculated for controls and Afadin-CKO mice. Scale bar, $50 \mu \mathrm{m}$. G, Quantification (mean \pm SEM) of the data in $F^{*} p<0.03$ by Student's $t$ test. $\boldsymbol{H}, \boldsymbol{I}$, , The number of mitotic cells is increased in Afadin-cKO mice. $\boldsymbol{H}$, Coronal section of control and Afadin-CKO brains at E13.5 brains showing the neocortex immunostained with pH3 (green) and Ki67 (red). Nuclei stained with DAPI are shown in blue. The percentage of the mitotic cells, immunostained with $\mathrm{pH} 3$, among the total number of dividing cells, immunostained with Ki67, was determined in controls and Afadin-cKO mice. Scale bar, $50 \mu \mathrm{m}$. I, Quantification (mean \pm SEM) of the data in $\boldsymbol{H} .{ }^{*} p<0.01$ by Student's $t$ test. Abbreviations as in Figure 3.
} 
A

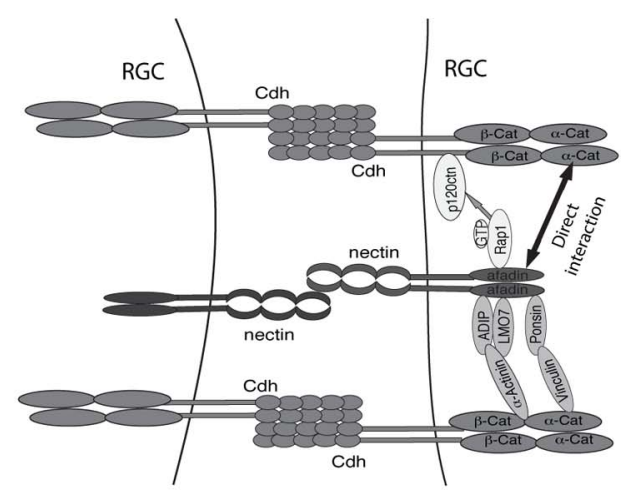

B

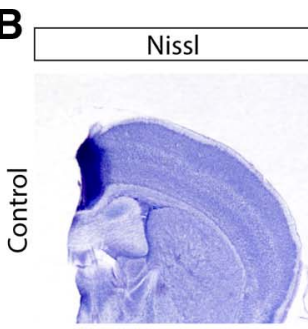

Rostral
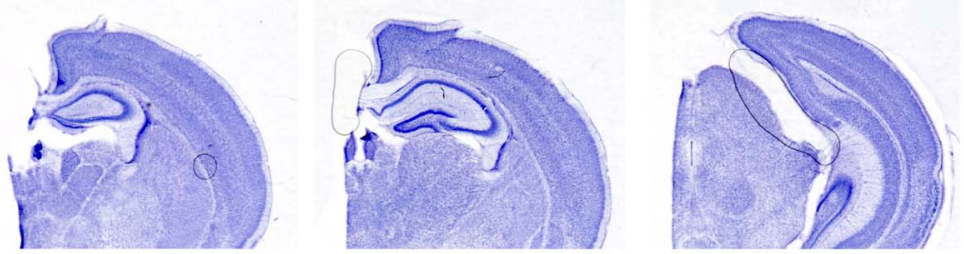

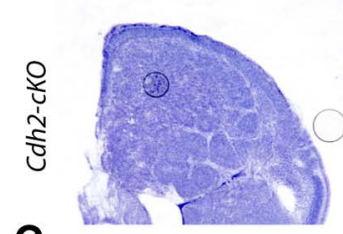

C
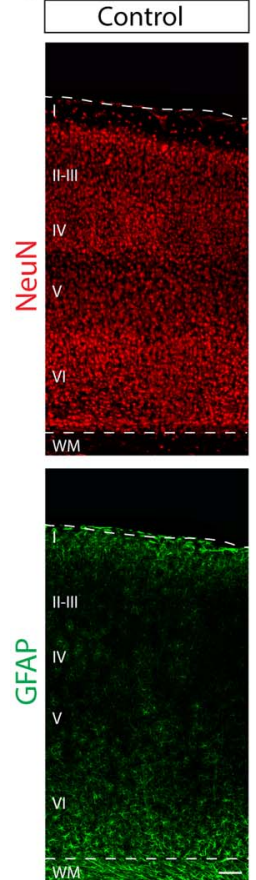
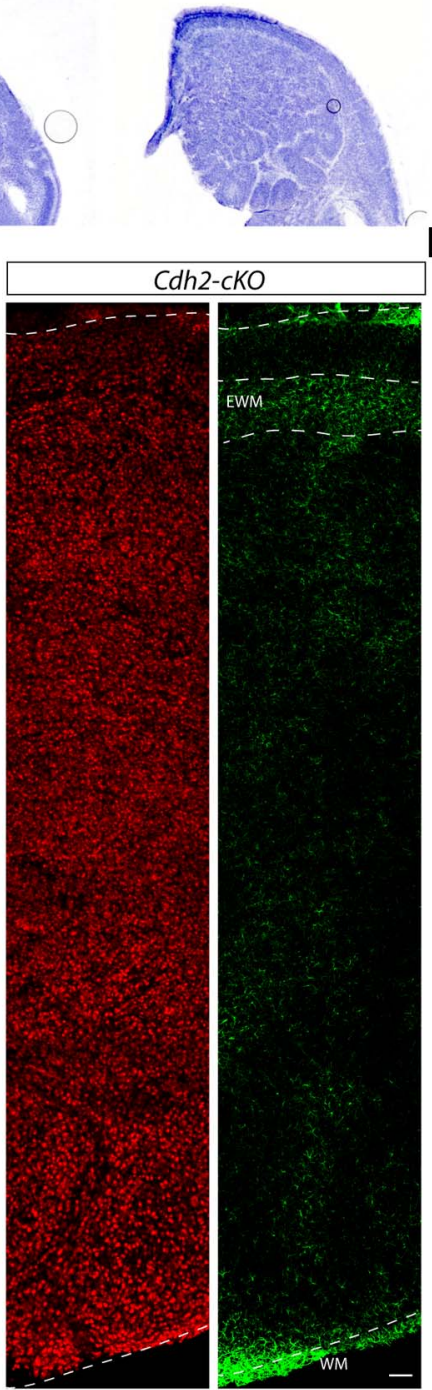
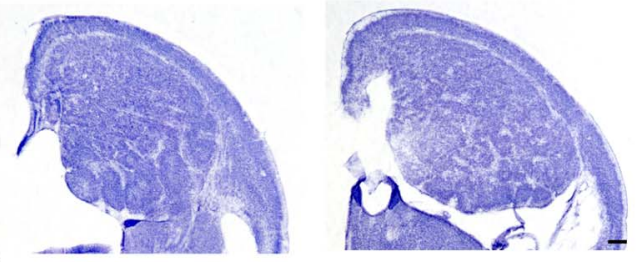

D
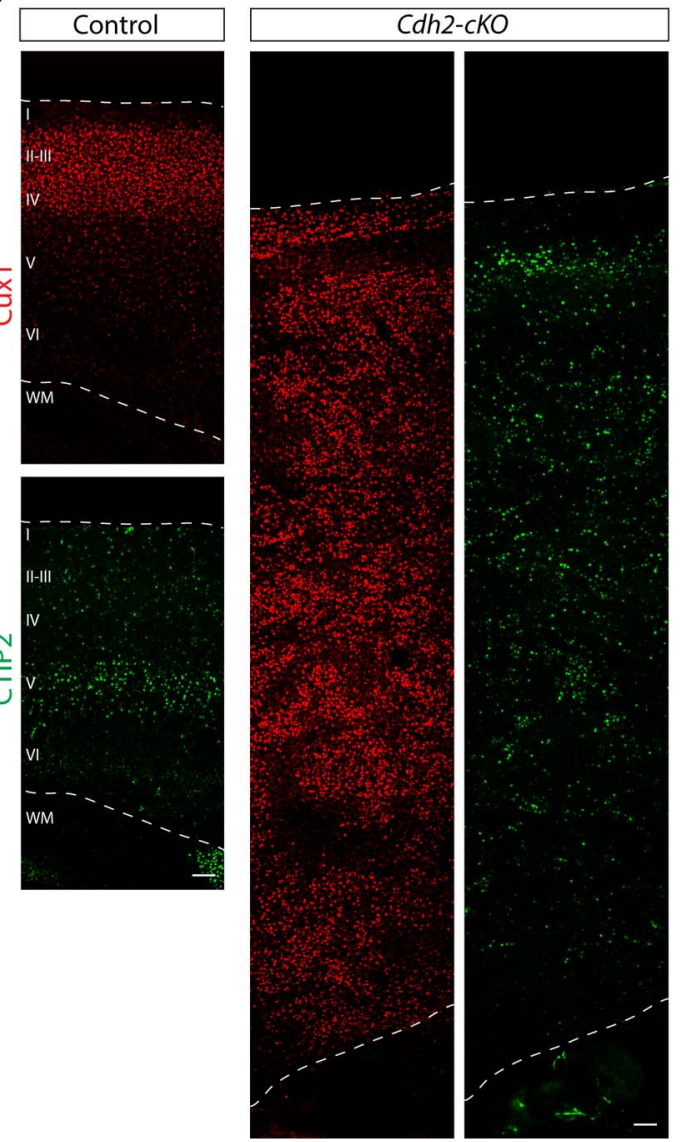

Figure 6. Cdh2 deletion in the cortical progenitors causes severe cortical lamination defects. $A$, Diagram showing the different interactions described for afadin and cadherins in adherens junction formation. B, Nissl staining showing coronal sections at several histological levels along the rostrocaudal axis of the neocortex of P13 brains of control and (dh2-cKO the (Figure legend continues.) 
Similarly to the afadin-cKO mice, the double immunostaining for Pax6 and Tbr2 revealed that the two markers were primarily expressed in different cell populations (Fig. 7C). Immunostaining using the cell cycle markers Ki67 and pH3 showed that dividing cells were distributed through the enlarged developing neocortex (Fig. 7E). Quantification of Pax6, Tbr2, and Ki67 at E13.5 confirmed massive increases in progenitor cell numbers and in their proliferation (Fig. $7 F$ ). Immunostaining with the axonal markers TAG1 and L1 at E16.5 (Fig. 7G,H) revealed a massive disorganization of the fibers in the Cdh2-cKO mice, similar to the alteration found for axonal tracts in Afadin-cKO. Therefore, we conclude that the phenotype of Cdh2-cKO mice closely resembles the phenotype of Afadin-cKO mice, leading to massively enhanced proliferation of progenitor cells and defects in neocortical development that ultimately lead to the formation of a severely disorganized cerebral cortex.

\section{Discussion}

The findings presented here show that the maintenance of adherens junctions between the end feet of RGCs in the VZ of the dorsal telencephalon is critical for the development of the normal laminar structure of the neocortex. When adherens junctions are genetically disrupted, by either perturbing afadin or $\mathrm{CDH} 2$, the structural integrity of the cortical VZ is compromised and progenitors disperse throughout the developing cortical wall. Progenitor proliferation is drastically increased, suggesting that the maintenance of adherens junctions is critical for controlled progenitor proliferation. We observed increases in proliferation not only in RGCs but also in intermediate progenitors, but the latter might have been affected secondarily as a result of the changes in the behavior of RGCs. Staining for Cux2 and CTIP2 revealed that projection neuron subtypes were still present but abnormally positioned in the mutants, indicating that adherens junctions are not essential for the generation of several major subtypes of projection neurons but for their positioning within appropriate neocortical cell layers.

Previous studies have demonstrated that the formation of adherens junctions between RGCs in the developing neocortex depends on $\mathrm{CDH} 2, \alpha \mathrm{E}$-catenin, and $\beta$-catenin (Machon et al., 2003; Lien et al., 2006; Kadowaki et al., 2007). We now show that afadin is also critical for this process. In its absence, key components of adherens junctions, such as $\mathrm{CDH} 2, \beta$-catenin, and $\alpha \mathrm{E}$-catenin, are no longer appropriately targeted to the apical end feet of RGCs, leading to disruptions of the neuroepithelial cell layer and dispersion of RGCs throughout the cortical wall. This suggests that afadin regulates adherens junction assembly between RGCs in similar ways as in epithelia outside the CNS in which it is critical to regulate the targeting and activity of the cadherin/ catenin complex (Fig. 6A; Takahashi et al., 1999; Hoshino et al., 2005). In epithelia, afadin connects the cadherin/catenin complex to nectins. Nectins are expressed in the cortical VZ (C.G.-S. and U.M., unpublished data), but their function in the formation of adherens junctions between RGCs still needs to be established.

$\leftarrow$

(Figure legend continued.) mice. Note hyperplastic and disorganized cortex and the presence of a cell-sparse region in the upper part of the cortex on top of a hyperplastic ectopia in Cdh2-cKO mice. Scale bar, $500 \mu \mathrm{m}$. C, Coronal sections of adult brains from control and Cdh2-cKO mice immunostained for the neuronal marker NeuN (red) and the astrocyte marker GFAP (green). Note the presence of GFAP ${ }^{+}$cells, presumably ectopic white matter, in the upper part of the cortex of Cdh2-cKO mice. Scale bar, $100 \mu \mathrm{m}$. D, Coronal sections of adult brains from control and Cdh2-cKO mice immunostained for Cux1 (red) and Ctip2 (green). Note the abnormal distribution of neuronal subtypes in Cdh2-cKO mice. Scale bar, $100 \mu \mathrm{m}$. Abbreviations as in Figure 1.
Interestingly, the maintenance of adherens junctions between RGCs also depends on numb and numb-like, which appear to exert their function at least in part by regulating cadherin function (Rasin et al., 2007). It will be interesting to test whether numb and numb-like cooperate with afadin to regulate the formation and maintenance of adherens junctions.

One of our most striking findings is the dramatic increase in progenitor proliferation in the absence of afadin and CDH2. Previous studies have shown that cell proliferation in the cortical VZ is increased in the absence of $\alpha \mathrm{E}$-catenin (Lien et al., 2006), but no changes have been reported in proliferation in the absence of afadin or CDH2 (Kadowaki et al., 2007). How can these differences be reconciled? In previous studies, Cre mice were used that lead to recombination $\sim 1$ day later than achieved with the Emx1Cre mouse line used here. The difference in timing is likely crucial. Recently, it has been demonstrated that Cre recombination mediated by nestin-Cre is not efficient in RGCs at early/midgestation (Liang et al., 2012). In fact, it has been shown that inactivation of afadin at the later time point using nestin-Cre leads to slow progressive and incomplete disruption of adherens junctions (Yamamoto et al., 2013), a phenotype that we have reproduced in our laboratory (C.G.-S. and U.M., unpublished data). Thus, delayed and possibly incomplete inactivation of afadin and CDH2 (Kadowaki et al., 2007) may have masked the proliferative defects described here. Moreover, proliferation was not analyzed in these animals, and adult mice were not evaluated. Overall, the published and our new findings show that disruption of adherens junctions by targeting three of their critical components ( $\alpha$ E-catenin, $\mathrm{CDH} 2$, afadin) leads to a similar proliferative defects, strongly suggesting that the maintenance of adherens junctions is critical for the control of cell proliferation. Because adherens junctions regulate cell polarity and affect the mitotic spindle in complex ways (Lu et al., 2001; Geldmacher-Voss et al., 2003; Harris and Peifer, 2007; Inaba et al., 2010), disruption of adherens junctions could lead in an imbalance of symmetric versus asymmetric cell divisions. Alternatively, disorganization of the $\mathrm{VZ}$ might affect how RGCs receive signals from other cells or via their cilia from the corticospinal fluid. Additional studies will be necessary to explore these possibilities.

Intriguingly, inactivation of the adherens junction component $\beta$-catenin in the cortical VZ leads to decreased progenitor proliferation (Machon et al., 2003; Woodhead et al., 2006; Tang et al., 2009). Conversely, overexpression of a stabilized $\beta$-catenin in neural progenitors delays their differentiation into neurons and leads to the expansion of the progenitor pool (Chenn and Walsh, 2002). These and other experiments (Chenn and Walsh, 2003 ) support the view that $\beta$-catenin is critical for the maintenance of the progenitor state of RGCs. Notably, $\beta$-catenin is not only a component of adherens junctions but also of the wnt signaling pathway (Wodarz and Nusse, 1998). Simultaneous perturbation of adherens junctions and wnt signaling likely affects progenitors in complex ways. $\beta$-Catenin might integrate signals from adherens junctions and wnt receptors to control the ultimate proliferative behavior of RGCs. In the mice reported here, $\beta$-catenin might be displaced from adherens junctions, leading to increased signaling to the nucleus, followed by increases in proliferation. Additionally, plakoblobin, which is closely related to $\beta$-catenin (Fukunaga et al., 2005), might contribute to signaling, but its function in the neocortex has not yet been evaluated.

Recent studies in the cortex of primates have identified a new progenitor type with radial glial properties that is neurogenic and has a long basal process (Fietz et al., 2010; Hansen et al., 2010). This progenitor type is located in the outer SVZ (OSVZ), which is 
A

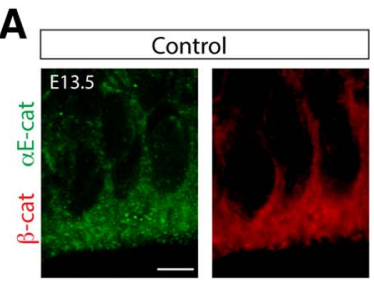

C

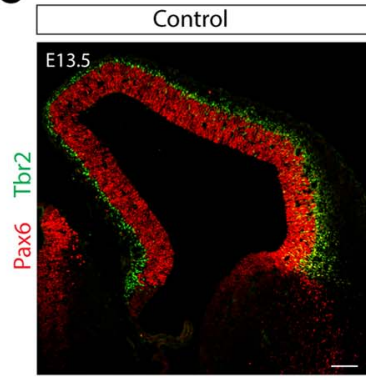

E

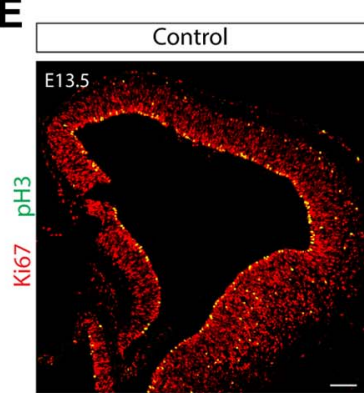

G

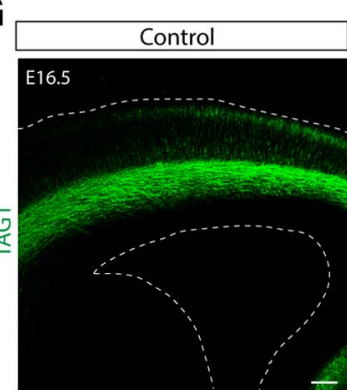

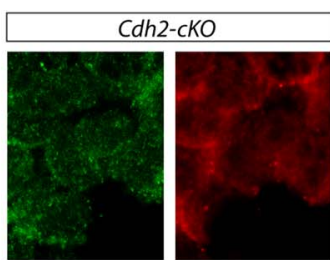

Cdh2-cKO

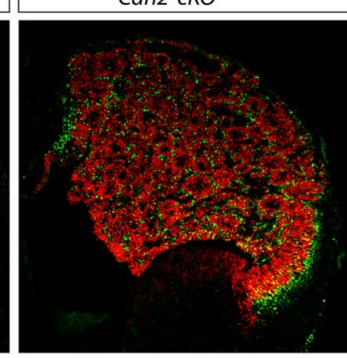

Cdh2-cKO
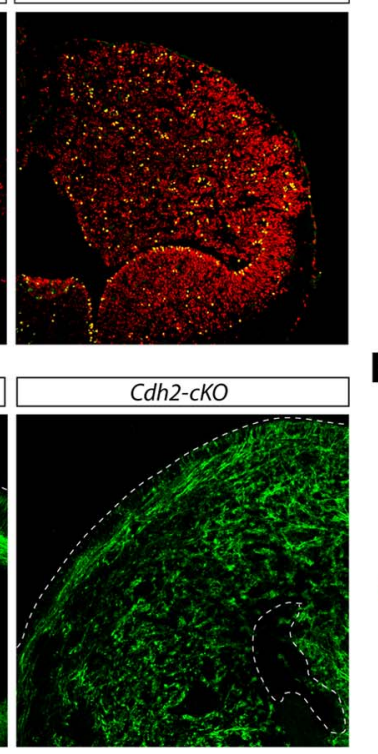

B

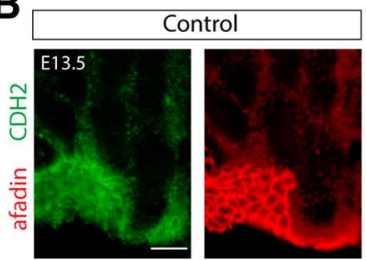

D

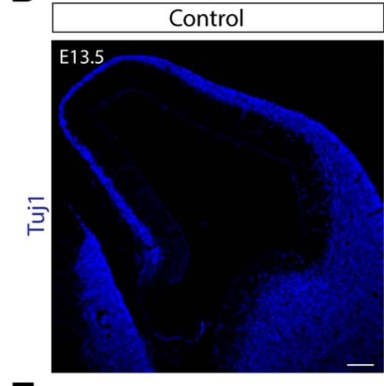

F

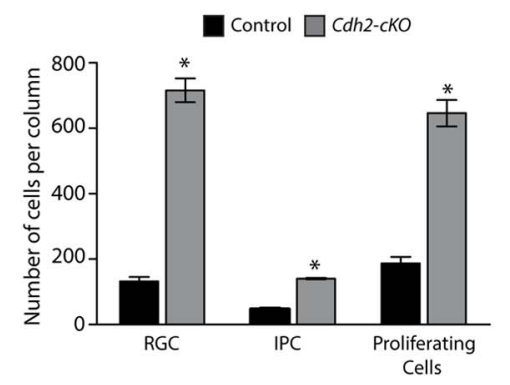

H

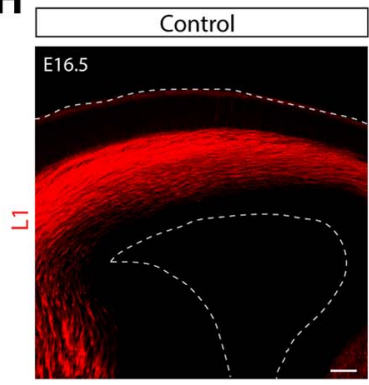

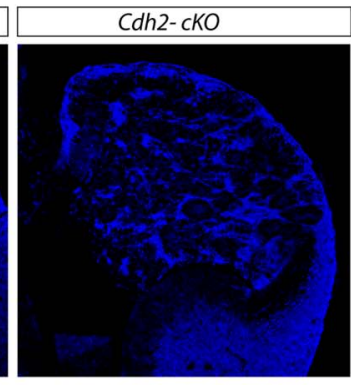
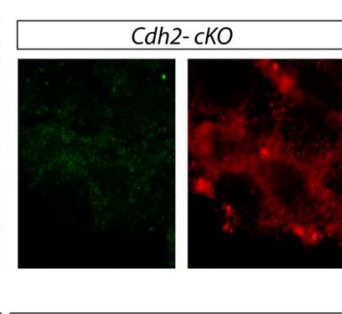

Cells
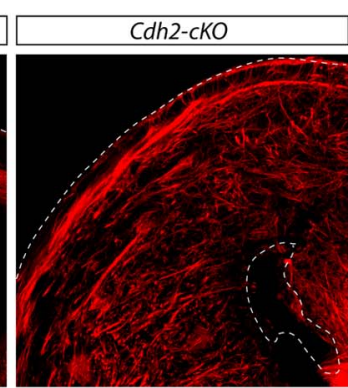

Figure 7. Disruption of adherens junctions and massively increased proliferation in the neocortex of Cdh2-cKO mice. $\boldsymbol{A}, \boldsymbol{B}$, Disruption of the apical-junctional complex in Cdh2-cKO mice as visualized by the immunostaining for $\beta$-catenin (red), $\alpha \mathrm{E}$-catenin (green; $\boldsymbol{A}$ ), as well as afadin (red) and $\mathrm{CDH} 2$ ( $\mathrm{green} ; \boldsymbol{B}$ ). Scale bars, $5 \mu \mathrm{m}$. $\boldsymbol{C}, 0$ verview of the developing neocortex from control and (dh2-cKO mice at E13.5 immunostained with the RGC marker Pax6 (red) and the intermediate progenitor marker Tbr2 (green). Note the cortical disorganization and severe hyperplasia in the mutant mice. Note that despite of the disorganization each marker is primarily expressed for different cell populations. Scale bar, $100 \mu \mathrm{m}$. $\boldsymbol{D}, 0 \mathrm{verview}$ of the developing neocortex from control and Cdh2-cKO mice atE13.5 immunostained with the neuronal marker Tuj1. Note the presence of multiple rosette-like structures in the $C \mathrm{dh} 2$-cKO mice. Scale bar, $100 \mu \mathrm{m}$. $\boldsymbol{E}$, 0 verview of the developing neocortex from control and (dh2-cKO mice at E13.5 immunostained with the Ki67 (red) and pH3 (green). Note the dramatic increase in the number of proliferative cells present in the enlarged cortex of the Cdh2 mutant mice. Scale bar, $100 \mu \mathrm{m}$. $\boldsymbol{F}$, Analysis of the number of Pax $6^{+}$cells, Tbr2 ${ }^{+}$cells, and Ki67 ${ }^{+}$cells in controls and Cdh2-cKO mice at E13.5 reveals massive increases in the number of progenitor cells in the developing cortex of the mutant mice (mean \pm SEM). ${ }^{*} p<0.0001$ by Student's $\boldsymbol{t}$ test. IPC, intermediate progenitor cells. $\boldsymbol{G}, \boldsymbol{H}$, Coronal brain sections from control and Cdh2-cKO mice at E16.5 were stained with antibodies to TAG1 (green) and L1 (red) to reveal axonal projections. Note the gross disorganization of axonal tracts in the mutants. Scale bars, $100 \mu \mathrm{m}$.

expanded massively in primates and especially in humans and has been proposed to be critical for the expansion of the neocortex during primate evolution. This OSVZ progenitor appears to rely on different signals for its expansion compared with RGCs in the VZ (Hansen et al., 2010; Stenzel et al., 2014). OSVZ progenitors lack apical processes and therefore the adherens junctions that normally connect the apical end feet of RGCs progenitors. In light of the data presented here, it is conceivable that downregulation of adherens junction proteins might be a critical step in the formation of these OSVZ progenitors. It will be interesting to evaluate the expression and function of cadherins and their associated signaling molecules in these important OSVZ progenitors.
Cell positioning in the neocortex is massively affected in the Afadin-cKO and Cdh2-cKO mice. It seems likely that several processes contribute to this defect. The end feet of the basal processes of RGCs are attached at the meninges. When adherens junctions between the end feet of apical processes of RGCs are disrupted, the cell bodies of RGCs likely are translocated away from the ventricle toward the meninges because of an imbalance in the tensile forces within their processes. As a consequence, the radial glia fiber network is disrupted, which is expected to affect migration. In addition, $\mathrm{CDH} 2$, nectins, and afadin are required for radial migration of cortical neurons (Kawauchi et al., 2010; Jossin and Cooper, 2011; Franco and Müller, 2013; Gil-Sanz et al., 
2013), suggesting that deletion of the genes encoding CDH2 and afadin already at the progenitor stage could produce cellautonomous defects in migrating neurons.

Our findings provide evidence that defects in adherensjunction components can lead to a phenotype resembling a double cortex. In humans, defects in neurons that affect their migration are most commonly thought to cause formation of a double cortex (Ross and Walsh, 2001; Bielas et al., 2004; Guerrini and Parrini, 2010). Surprisingly, inactivation of the murine homologs of the genes mutated in human neuronal migration disorders, such as $D C X$, have failed to reproduce these malformations (Corbo et al., 2002), which could be a consequence of the higher complexity and larger size of the human neocortex in which cells have to migrate larger distances than in mice. However, in mice mutations in RhoA that affect RGCs lead to a double cortex-like phenotype (Cappello et al., 2012). These findings and the results presented here suggest that it will be interesting to determine whether mutations in human genes that affect adherens junctions between RGCs are mechanistically linked to the formation of a double cortex.

\section{References}

Ayala R, Shu T, Tsai LH (2007) Trekking across the brain: the journey of neuronal migration. Cell 128:29-43. CrossRef Medline

Barkovich AJ, Guerrini R, Battaglia G, Kalifa G, N'Guyen T, Parmeggiani A, Santucci M, Giovanardi-Rossi P, Granata T, D’Incerti L (1994) Band heterotopia: correlation of outcome with magnetic resonance imaging parameters. Ann Neurol 36:609-617. CrossRef Medline

Bielas S, Higginbotham H, Koizumi H, Tanaka T, Gleeson JG (2004) Cortical neuronal migration mutants suggest separate but intersecting pathways. Annu Rev Cell Dev Biol 20:593-618. CrossRef Medline

Brault V, Moore R, Kutsch S, Ishibashi M, Rowitch DH, McMahon AP, Sommer L, Boussadia O, Kemler R (2001) Inactivation of the betacatenin gene by Wnt1-Cre-mediated deletion results in dramatic brain malformation and failure of craniofacial development. Development 128: 1253-1264. Medline

Caccamo D, Katsetos CD, Herman MM, Frankfurter A, Collins VP, Rubinstein LJ (1989) Immunohistochemistry of a spontaneous murine ovarian teratoma with neuroepithelial differentiation. Neuron-associated beta-tubulin as a marker for primitive neuroepithelium. Lab Invest 60 : 390-398. Medline

Cappello S, Böhringer CRJ, Bergami M, Conzelmann KK, Ghanem A, Tomassy GS, Arlotta P, Mainardi M, Allegra M, Caleo M, van Hengel J, Brakebusch C, Götz M (2012) A radial glia-specific role of RhoA in double cortex formation. Neuron 73:911-924. CrossRef Medline

Chenn A, Walsh CA (2002) Regulation of cerebral cortical size by control of cell cycle exit in neural precursors. Science 297:365-369. CrossRef Medline

Chenn A, Walsh CA (2003) Increased neuronal production, enlarged forebrains and cytoarchitectural distortions in beta-catenin overexpressing transgenic mice. Cereb Cortex 13:599-606. CrossRef Medline

Corbo JC, Deuel TA, Long JM, LaPorte P, Tsai E, Wynshaw-Boris A, Walsh CA (2002) Doublecortin is required in mice for lamination of the hippocampus but not the neocortex. J Neurosci 22:7548-7557. Medline

des Portes V, Pinard JM, Billuart P, Vinet MC, Koulakoff A, Carrié A, Gelot A, Dupuis E, Motte J, Berwald-Netter Y, Catala M, Kahn A, Beldjord C, Chelly J (1998) A novel CNS gene required for neuronal migration and involved in X-linked subcortical laminar heterotopia and lissencephaly syndrome. Cell 92:51-61. CrossRef Medline

Dobyns WB, Truwit CL, Ross ME, Matsumoto N, Pilz DT, Ledbetter DH, Gleeson JG, Walsh CA, Barkovich AJ (1999) Differences in the gyral pattern distinguish chromosome 17-linked and X-linked lissencephaly. Neurology 53:270-277. CrossRef Medline

Dubois NC, Hofmann D, Kaloulis K, Bishop JM, Trumpp A (2006) NestinCre transgenic mouse line Nes-Crel mediates highly efficient Cre/loxP mediated recombination in the nervous system, kidney, and somitederived tissues. Genesis 44:355-360. CrossRef Medline

Englund C, Fink A, Lau C, Pham D, Daza RAM, Bulfone A, Kowalczyk T, Hevner RF (2005) Pax6, Tbr2, and Tbr1 are expressed sequentially by radial glia, intermediate progenitor cells, and postmitotic neurons in developing neocortex. J Neurosci 25:247-251. CrossRef Medline
Ferland RJ, Batiz LF, Neal J, Lian G, Bundock E, Lu J, Hsiao YC, Diamond R, Mei D, Banham AH, Brown PJ, Vanderburg CR, Joseph J, Hecht JL, Folkerth R, Guerrini R, Walsh CA, Rodriguez EM, Sheen VL (2009) Disruption of neural progenitors along the ventricular and subventricular zones in periventricular heterotopia. Hum Mol Genet 18:497-516. CrossRef Medline

Fietz SA, Kelava I, Vogt J, Wilsch-Bräuninger M, Stenzel D, Fish JL, Corbeil D, Riehn A, Distler W, Nitsch R, Huttner WB (2010) OSVZ progenitors of human and ferret neocortex are epithelial-like and expand by integrin signaling. Nat Neurosci 13:690-699. CrossRef Medline

Fishell G, Kriegstein AR (2003) Neurons from radial glia: the consequences of asymmetric inheritance. Curr Opin Neurobiol 13:34-41. CrossRef Medline

Franco SJ, Müller U (2013) Shaping our minds: stem and progenitor cell diversity in the mammalian neocortex. Neuron 77:19-34. CrossRef Medline

Franco SJ, Martinez-Garay I, Gil-Sanz C, Harkins-Perry SR, Müller U (2011) Reelin regulates cadherin function via Dab1/Rap1 to control neuronal migration and lamination in the neocortex. Neuron 69:482-497. CrossRef Medline

Franco SJ, Gil-Sanz C, Martinez-Garay I, Espinosa A, Harkins-Perry SR, Ramos C, Müller U (2012) Fate-restricted neural progenitors in the mammalian cerebral cortex. Science 337:746-749. CrossRef Medline

Fukunaga Y, Liu H, Shimizu M, Komiya S, Kawasuji M, Nagafuchi A (2005) Defining the roles of beta-catenin and plakoglobin in cell-cell adhesion: isolation of beta-catenin/plakoglobin-deficient F9 cells. Cell Struct Funct 30:25-34. CrossRef Medline

Geldmacher-Voss B, Reugels AM, Pauls S, Campos-Ortega JA (2003) A 90degree rotation of the mitotic spindle changes the orientation of mitoses of zebrafish neuroepithelial cells. Development 130:3767-3780. CrossRef Medline

Gil-Sanz C, Franco SJ, Martinez-Garay I, Espinosa A, Harkins-Perry S, Müller U (2013) Cajal-Retzius cells instruct neuronal migration by coincidence signaling between secreted and contact-dependent guidance cues. Neuron 79:461-477. CrossRef Medline

Gleeson JG, Allen KM, Fox JW, Lamperti ED, Berkovic S, Scheffer I, Cooper EC, Dobyns WB, Minnerath SR, Ross ME, Walsh CA (1998) Doublecortin, a brain-specific gene mutated in human X-linked lissencephaly and double cortex syndrome, encodes a putative signaling protein. Cell 92:6372. CrossRef Medline

Gorski JA, Talley T, Qiu M, Puelles L, Rubenstein JLR, Jones KR (2002) Cortical excitatory neurons and glia, but not GABAergic neurons, are produced in the Emxl-expressing lineage. J Neurosci 22:6309-6314. Medline

Götz M, Stoykova A, Gruss P (1998) Pax6 controls radial glia differentiation in the cerebral cortex. Neuron 21:1031-1044. CrossRef Medline

Greig LC, Woodworth MB, Galazo MJ, Padmanabhan H, Macklis JD (2013) Molecular logic of neocortical projection neuron specification, development and diversity. Nat Rev Neurosci 14:755-769. CrossRef Medline

Guerrini R, Parrini E (2010) Neuronal migration disorders. Neurobiol Dis 38:154-166. CrossRef Medline

Hansen DV, Lui JH, Parker PRL, Kriegstein AR (2010) Neurogenic radial glia in the outer subventricular zone of human neocortex. Nature 464: 554-561. CrossRef Medline

Harris TJC, Peifer M (2007) aPKC controls microtubule organization to balance adherens junction symmetry and planar polarity during development. Dev Cell 12:727-738. CrossRef Medline

Herrenknecht K, Ozawa M, Eckerskorn C, Lottspeich F, Lenter M, Kemler R (1991) The uvomorulin-anchorage protein alpha catenin is a vinculin homologue. Proc Natl Acad Sci U S A 88:9156-9160. CrossRef Medline

Hirano S, Kimoto N, Shimoyama Y, Hirohashi S, Takeichi M (1992) Identification of a neural alpha-catenin as a key regulator of cadherin function and multicellular organization. Cell 70:293-301. CrossRef Medline

Hoshino T, Sakisaka T, Baba T, Yamada T, Kimura T, Takai Y (2005) Regulation of E-cadherin endocytosis by nectin through afadin, Rap1, and p120ctn. J Biol Chem 280:24095-24103. CrossRef Medline

Ikeda W, Nakanishi H, Miyoshi J, Mandai K, Ishizaki H, Tanaka M, Togawa A, Takahashi K, Nishioka H, Yoshida H, Mizoguchi A, Nishikawa S, Takai Y (1999) Afadin: a key molecule essential for structural organization of cell-cell junctions of polarized epithelia during embryogenesis. J Cell Biol 146:1117-1132. CrossRef Medline

Inaba M, Yuan H, Salzmann V, Fuller MT, Yamashita YM (2010) E-cadherin is required for centrosome and spindle orientation in Drosophila male germline stem cells. PLoS One 5:e12473. CrossRef Medline Iwasato T, Nomura R, Ando R, Ikeda T, Tanaka M, Itohara S (2004) Dorsal 
telencephalon-specific expression of Cre recombinase in PAC transgenic mice. Genesis 38:130-138. CrossRef Medline

Jossin Y, Cooper JA (2011) Reelin, Rap1 and N-cadherin orient the migration of multipolar neurons in the developing neocortex. Nat Neurosci 14:697-703. CrossRef Medline

Junghans D, Hack I, Frotscher M, Taylor V, Kemler R (2005) Beta-cateninmediated cell-adhesion is vital for embryonic forebrain development. Dev Dyn 233:528-539. CrossRef Medline

Kadowaki M, Nakamura S, Machon O, Krauss S, Radice GL, Takeichi M (2007) N-cadherin mediates cortical organization in the mouse brain. Dev Biol 304:22-33. CrossRef Medline

Kawauchi T, Sekine K, Shikanai M, Chihama K, Tomita K, Kubo K, Nakajima K, Nabeshima Y, Hoshino M (2010) Rab GTPases-dependent endocytic pathways regulate neuronal migration and maturation through $\mathrm{N}$-cadherin trafficking. Neuron 67:588-602. CrossRef Medline

Knudsen KA, Wheelock MJ (1992) Plakoglobin, or an 83-kD homologue distinct from beta-catenin, interacts with E-cadherin and $\mathrm{N}$-cadherin. J Cell Biol 118:671-679. CrossRef Medline

Kriegstein AR, Noctor SC (2004) Patterns of neuronal migration in the embryonic cortex. Trends Neurosci 27:392-399. CrossRef Medline

Lee MK, Rebhun LI, Frankfurter A (1990a) Posttranslational modification of class III beta-tubulin. Proc Natl Acad Sci U S A 87:7195-7199. CrossRef Medline

Lee MK, Tuttle JB, Rebhun LI, Cleveland DW, Frankfurter A (1990b) The expression and posttranslational modification of a neuron-specific betatubulin isotype during chick embryogenesis. Cell Motil Cytoskeleton 17: 118-132. CrossRef Medline

Liang H, Hippenmeyer S, Ghashghaei HT (2012) A Nestin-cre transgenic mouse is insufficient for recombination in early embryonic neural progenitors. Biol Open 1:1200-1203. CrossRef Medline

Lien WH, Klezovitch O, Fernandez TE, Delrow J, Vasioukhin V (2006) alphaE-catenin controls cerebral cortical size by regulating the hedgehog signaling pathway. Science 311:1609-1612. CrossRef Medline

Li HS, Wang D, Shen Q, Schonemann MD, Gorski JA, Jones KR, Temple S, Jan LY, Jan YN (2003) Inactivation of Numb and Numblike in embryonic dorsal forebrain impairs neurogenesis and disrupts cortical morphogenesis. Neuron 40:1105-1118. CrossRef Medline

Lu B, Roegiers F, Jan LY, Jan YN (2001) Adherens junctions inhibit asymmetric division in the Drosophila epithelium. Nature 409:522-525. CrossRef Medline

Machon O, van den Bout CJ, Backman M, Kemler R, Krauss S (2003) Role of beta-catenin in the developing cortical and hippocampal neuroepithelium. Neuroscience 122:129-143. CrossRef Medline

Miyahara M, Nakanishi H, Takahashi K, Satoh-Horikawa K, Tachibana K, Takai Y (2000) Interaction of nectin with afadin is necessary for its clustering at cell-cell contact sites but not for its cis dimerization or trans interaction. J Biol Chem 275:613-618. CrossRef Medline

Nagafuchi A, Takeichi M, Tsukita S (1991) The $102 \mathrm{kd}$ cadherin-associated protein: similarity to vinculin and posttranscriptional regulation of expression. Cell 65:849-857. CrossRef Medline

Ozawa M, Baribault H, Kemler R (1989) The cytoplasmic domain of the cell adhesion molecule uvomorulin associates with three independent proteins structurally related in different species. EMBO J 8:1711-1717. Medline

Ozawa M, Ringwald M, Kemler R (1990) Uvomorulin-catenin complex formation is regulated by a specific domain in the cytoplasmic region of the cell adhesion molecule. Proc Natl Acad Sci U S A 87:4246-4250. CrossRef Medline

Pokutta S, Drees F, Takai Y, Nelson WJ, Weis WI (2002) Biochemical and structural definition of the 1-afadin- and actin-binding sites of alphacatenin. J Biol Chem 277:18868-18874. CrossRef Medline

Rakic P (2003) Developmental and evolutionary adaptations of cortical radial glia. Cereb Cortex 13:541-549. CrossRef Medline

Rasin MR, Gazula VR, Breunig JJ, Kwan KY, Johnson MB, Liu-Chen S, Li HS, Jan LY, Jan YN, Rakic P, Sestan N (2007) Numb and Numbl are required for maintenance of cadherin-based adhesion and polarity of neural progenitors. Nat Neurosci 10:819-827. CrossRef Medline

Reynolds AB, Herbert L, Cleveland JL, Berg ST, Gaut JR (1992) p120, a novel substrate of protein tyrosine kinase receptors and of p60v-src, is related to cadherin-binding factors beta-catenin, plakoglobin and armadillo. Oncogene 7:2439-2445. Medline

Ross ME, Walsh CA (2001) Human brain malformations and their lessons for neuronal migration. Annu Rev Neurosci 24:1041-1070. CrossRef Medline

Ryder E, Gleeson D, Sethi D, Vyas S, Miklejewska E, Dalvi P, Habib B, Cook R, Hardy M, Jhaveri K, Bottomley J, Wardle-Jones H, Bussell JN, Houghton R, Salisbury J, Skarnes WC, Ramirez-Solis R (2013) Molecular characterization of mutant mouse strains generated from the EUCOMM/KOMP-CSD ES cell resource. Mamm Genome 24:286-294. CrossRef Medline

Sato T, Fujita N, Yamada A, Ooshio T, Okamoto R, Irie K, Takai Y (2006) Regulation of the assembly and adhesion activity of E-cadherin by nectin and afadin for the formation of adherens junctions in Madin-Darby canine kidney cells. J Biol Chem 281:5288-5299. CrossRef Medline

Sheen VL, Ganesh VS, Topcu M, Sebire G, Bodell A, Hill RS, Grant PE, Shugart YY, Imitola J, Khoury SJ, Guerrini R, Walsh CA (2004) Mutations in ARFGEF2 implicate vesicle trafficking in neural progenitor proliferation and migration in the human cerebral cortex. Nat Genet 36:69-76. CrossRef Medline

Stenzel D, Wilsch-Bräuninger M, Wong FK, Heuer H, Huttner WB (2014) Integrin $\alpha \mathrm{v} \beta 3$ and thyroid hormones promote expansion of progenitors in embryonic neocortex. Development 141:795-806. CrossRef Medline

Tachibana K, Nakanishi H, Mandai K, Ozaki K, Ikeda W, Yamamoto Y, Nagafuchi A, Tsukita S, Takai Y (2000) Two cell adhesion molecules, nectin and cadherin, interact through their cytoplasmic domainassociated proteins. J Cell Biol 150:1161-1176. CrossRef Medline

Takahashi K, Nakanishi H, Miyahara M, Mandai K, Satoh K, Satoh A, Nishioka H, Aoki J, Nomoto A, Mizoguchi A, Takai Y (1999) Nectin/PRR: an immunoglobulin-like cell adhesion molecule recruited to cadherin-based adherens junctions through interaction with Afadin, a PDZ domaincontaining protein. J Cell Biol 145:539-549. CrossRef Medline

Tang M, Miyamoto Y, Huang EJ (2009) Multiple roles of beta-catenin in controlling the neurogenic niche for midbrain dopamine neurons. Development 136:2027-2038. CrossRef Medline

Wodarz A, Nusse R (1998) Mechanisms of Wnt signaling in development. Annu Rev Cell Dev Biol 14:59-88. CrossRef Medline

Woodhead GJ, Mutch CA, Olson EC, Chenn A (2006) Cell-autonomous beta-catenin signaling regulates cortical precursor proliferation. J Neurosci 26:12620-12630. CrossRef Medline

Yamamoto H, Maruo T, Majima T, Ishizaki H, Tanaka-Okamoto M, Miyoshi J, Mandai K, Takai Y (2013) Genetic deletion of afadin causes hydrocephalus by destruction of adherens junctions in radial glial and ependymal cells in the midbrain. PLoS One 8:e80356-e80356. CrossRef Medline 